OPEN ACCESS

Edited by:

Edna Hillmann

Humboldt-Universität zu Berlin,

Germany

Reviewed by:

Nils Fall,

Swedish University of Agricultural

Sciences, Sweden

Christoph Winckler

Universität für Bodenkultur Wien,

Austria

*Correspondence:

Francesca Marcato

francesca.marcato@wur.n

Specialty section:

This article was submitted to Animal Behavior and Welfare,

a section of the journal

Frontiers in Veterinary Science

Received: 21 November 2017

Accepted: 30 May 2018

Published: 21 June 2018

Citation:

Marcato $F$, van den Brand $H, K e m p ~ B$ and van Reenen K (2018) Evaluating

Potential Biomarkers of Health and

Performance in Veal Calves.

Front. Vet. Sci. 5:133

doi: 10.3389/fvets.2018.00133

\section{Evaluating Potential Biomarkers of Health and Performance in Veal Calves}

\author{
Francesca Marcato ${ }^{1,2 *}$, Henry van den Brand ${ }^{1}$, Bas Kemp ${ }^{1}$ and Kees van Reenen ${ }^{2}$ \\ ${ }^{1}$ Adaptation Physiology Group, Wageningen University \& Research, Wageningen, Netherlands, ${ }^{2}$ Animal Production Systems \\ Group, Livestock Research, Wageningen University \& Research, Wageningen, Netherlands
}

Veal calves undergo many challenges in the early stages of their life. Such challenges, including mixing procedures and transportation of calves to the veal farm, may have a negative influence on growth rate, feed intake, metabolism, immunity and disease susceptibility of calves. As a consequence, many hematological, physiological, metabolic and immunological parameters of stressed calves might be altered on arrival at the veal farm. Some of these response variables might be useful as biomarkers of performance of calves at the veal farm as they might provide information about an ongoing disease process, or may predict future diseases. Biomarkers might be helpful to group and manage calves in different risk categories after arrival. By adopting treatment decisions and protocols on a risk-group or individual basis, it would be possible to improve animal health and reduce both disease incidence and antibiotic use. Moreover, the use of biomarkers might be an economically feasible approach as some of them do not need invasive techniques and others can be measured in blood already taken during routine checks. Previous literature mainly assessed the physiological responses of calves to transportation. However, information on the link between on-farm arrival data and future health and performance of veal calves is limited. This review, therefore, examined a wide range of papers and aimed to identify potential biomarkers of future health and performance.

\section{Keywords: veal calves, challenges, health, diseases, biomarkers, stress}

\section{INTRODUCTION}

The veal industry plays an important role worldwide as side market of the dairy industry (1). Europe is the main veal producer, accounting for $82 \%$ of the global production in 2010. Within the European context France, the Netherlands and Italy are the leading veal producing countries with a global market share of 27,25, and 16\%, respectively (2). Belgium and Germany represent 6 and 5\% of global veal production, whereas other European countries either have a small veal sector such as Switzerland, or no veal production due to animal welfare restrictions such as the Scandinavian countries. Outside Europe, veal production is relatively limited; main veal producing countries outside Europe include the United States, with Canada, Australia and New Zealand each accounting for 3 to $6 \%$ of global production (1). The current review will focus on the European scenario because Europe is the leader in veal production. 
White veal calves face many challenges in the pre-weaning period (3). These challenges include birth, transportation, mixing procedures, inappropriate management conditions and new housing environments (4). At the dairy farm, separation of calves from their dams usually occurs immediately after birth. Subsequently, when calves are 14-20 days of age, they are gathered from different dairy farms and transported to a collection center, followed by another transport to the veal farm (4). During these phases, calves from different farms are mixed and are exposed to new environmental conditions and management practices. All these challenges occur at an age at which the calf is immature and several physiological systems are still developing. For example, young calves are still developing their gastrointestinal tract (GIT), and their thermoregulatory (5) and acquired immune systems (6) are not completely functional yet. During the first week of life calves may be exposed to pathogens against which they may not have (maternal) antibodies $(7,8)$. The combination of the indicated challenges and the immature physiological systems of the calves may explain the high susceptibility of calves to infections. As a result, calf health and performance at the veal farm are affected $(3,9)$. Calves may develop diseases, among which respiratory diseases (e.g., bovine respiratory diseases, BRD) and enteric diseases are most frequently observed (10-12).

Respiratory diseases are common health disorders in veal calves, which have a severe impact on both animal welfare and the income of producers, because they are the most important causes of morbidity and mortality $(13,14)$. According to Pardon et al. (11), BRD incidence in veal calves during the rearing period ranges between 4.6 and $43.8 \%$, with an average of $17 \%$. The same authors reported that of the $5.7 \%$ of veal calves which died before the end of the production cycle, $27.1 \%$ had suffered of pneumonia. Approximately two thirds of calves diagnosed with pneumonia were individually treated for BRD. Post-mortem analysis of lungs at slaughter (4) revealed that $21.4 \%$ of veal calves showed signs of pleuritis and 13.9 and $7.7 \%$ signs of pneumonia, respectively. Bovine respiratory disease is characterized by many clinical signs, including nasal discharge, coughing, fever, inappetence, apathy and hampered respiration (4). Both subclinical and clinical signs hamper the growth and welfare of infected calves compared with healthy animals (15). Bovine respiratory disease is a complex disease that depends on different interacting factors. The etiology of this respiratory disorder involves several infectious agents, such as bacteria, mycoplasma and viruses, that act in synergy with stressors, like weaning, transportation, nutrition and rearing environment $(16,17)$. Viruses which contribute to the outspread of BRD are mainly bovine respiratory syncytial virus (BRSV), parainfluenza-3 virus (PI3V) and bovine viral diarrhea virus (BVDV) (16).

Enteritis is another disease that is frequently diagnosed during early stages of life and it is particularly seen in the first 3 weeks after arrival of calves at the veal farm (11). Pardon et al. (11) showed that, of $5.7 \%$ of calves which died, $7.5 \%$ had suffered from enteritis. Different microorganisms, including bacteria, viruses, protozoa and yeasts are responsible for enteric diseases (18). Escherichia coli, Salmonella sp., and rotavirus are the most common microorganisms, causing enteric diseases and diarrhea in young calves (19).

In an attempt to counteract the negative effects of diseases, the use of therapeutic treatments has become widespread (20). The use of antimicrobial growth promoters has been banned in Europe since 2006 (21), but since then the use of therapeutic antimicrobials increased (22). A recent study demonstrated that antimicrobial use in veal calves is the highest of all food producing animals (10). Pardon et al. (23) reported that in Belgium the antimicrobial consumption in white veal calves is approximately 25.2 tons per year. In the Netherlands, one of the main veal producing countries in Europe, that has similar veal production systems as Belgium, a reduction in antimicrobial use in veal production has already been achieved during recent years. However, the usage of antimicrobials is considered still high $(10,24)$. There is growing public concern about the consequences of feeding antibiotics (especially oral treatments) to farm animals, including veal calves, for both human and animal health (e.g., a massive use of antibiotics may cause antibiotic resistance) (20, 25). Therefore, there is a strong need for management strategies in the veal sector that may help to reduce the incidence of diseases and, consequently, antibiotic use.

\section{CLINICAL UTILITY OF POTENTIAL BIOMARKERS IN VEAL CALVES: FUTURE IMPLICATIONS}

This review builds on the idea that response variables obtained in calves on arrival at the veal farm may be used as predictors or biomarkers of later health and performance. A biomarker, per definition, is a marker of a biological process or state and it can provide information on a current status or future risk of disease of an individual (26). The availability of such biomarkers would be helpful, for example, to identify individual calves at an early stage with an enhanced probability to develop disease, and to take preventive measures before clinical problems occur. At herd level, biomarkers might be used for profiling calves according to the magnitude of stress they have experienced and their predisposition to develop future diseases (27). Grouping of calves in different risk categories should help the farmer in managing calves at arrival. By adopting handling procedures, treatment decisions and protocols on a risk-group or individual basis, farmers might be able to better meet individual animal needs and improve the health and welfare of calves throughout the veal production chain [see also Renaud et al. (28)]. Collectively, this may reduce the incidence of disease as well as the use of antibiotics.

Previous studies (29-32) examined effects of different transport conditions and duration on calf blood constituents and performance of calves at their arrival at the veal farm. Only a limited number of studies $(30,33,34)$ assessed relationships between on-arrival blood constituents and future performance of calves at the veal farm. By examining a much wider range of papers, this review aimed to identify potential on-farm biomarkers of health and performance of calves at the veal farm. 


\section{EFFECTS OF ENVIRONMENTAL CHALLENGES ON PHYSIOLOGICAL PATHWAYS AND ON BIOMARKERS}

Environmental challenges, including road transportation, are known to affect metabolic (35), physiological (36), immunological (37-39) and behavioral responses $(36,40)$ of calves. As illustrated in Figure 1, exposure of the animal to environmental challenges can be short-term or prolonged. In both cases, an increase in plasma concentrations of glucocorticoids and cortisol is observed. In case of short exposure, a peak production in glucocorticoids determines an acute stress response. As a result, a calf might experience changes in its biological functions, with shifts in energy sources that allow the animal to better cope with the stressor. Moreover, an activation of the immune system, including enhanced cell function, cell-mediated, humoral and innate immunity, might protect calf health (41). All these changes might restore homeostasis in the short-term and not affect animal health and welfare on the long run. In case of prolonged exposure, persistent higher concentrations of glucocorticoids may lead to prolonged/chronic stress response (Figure 1). Under these circumstances, the activation of the hypothalamic-pituitaryadrenal (HPA) axis is responsible for long-lasting effects on the animal body. Effects include changes in catecholamine release, growth hormone $(\mathrm{GH})$ secretion and modulation of thyroid-stimulating hormones. Additionally, calves might experience BW losses due to increased dehydration and nutrient mobilization accompanied by changes in rectal temperature, enzymes concentrations in the blood and a suppression of the immune function. As a consequence of prolonged stress exposure, calves may experience changes of biological functions to an extent that the risk of developing diseases is increased (42). This review will first focus on the main effects of HPA axis activation as one of the main pathways between exposure to environmental challenges and susceptibility to disease will be discussed. Therefore, a description in changes in cortisol and BW will be reported. The current review will first discuss dehydration-related variables and then variables associated with nutrient metabolism. Then changes in rectal temperature, immune cells and enzyme concentrations will be discussed. Interactions between different physiological variables and details

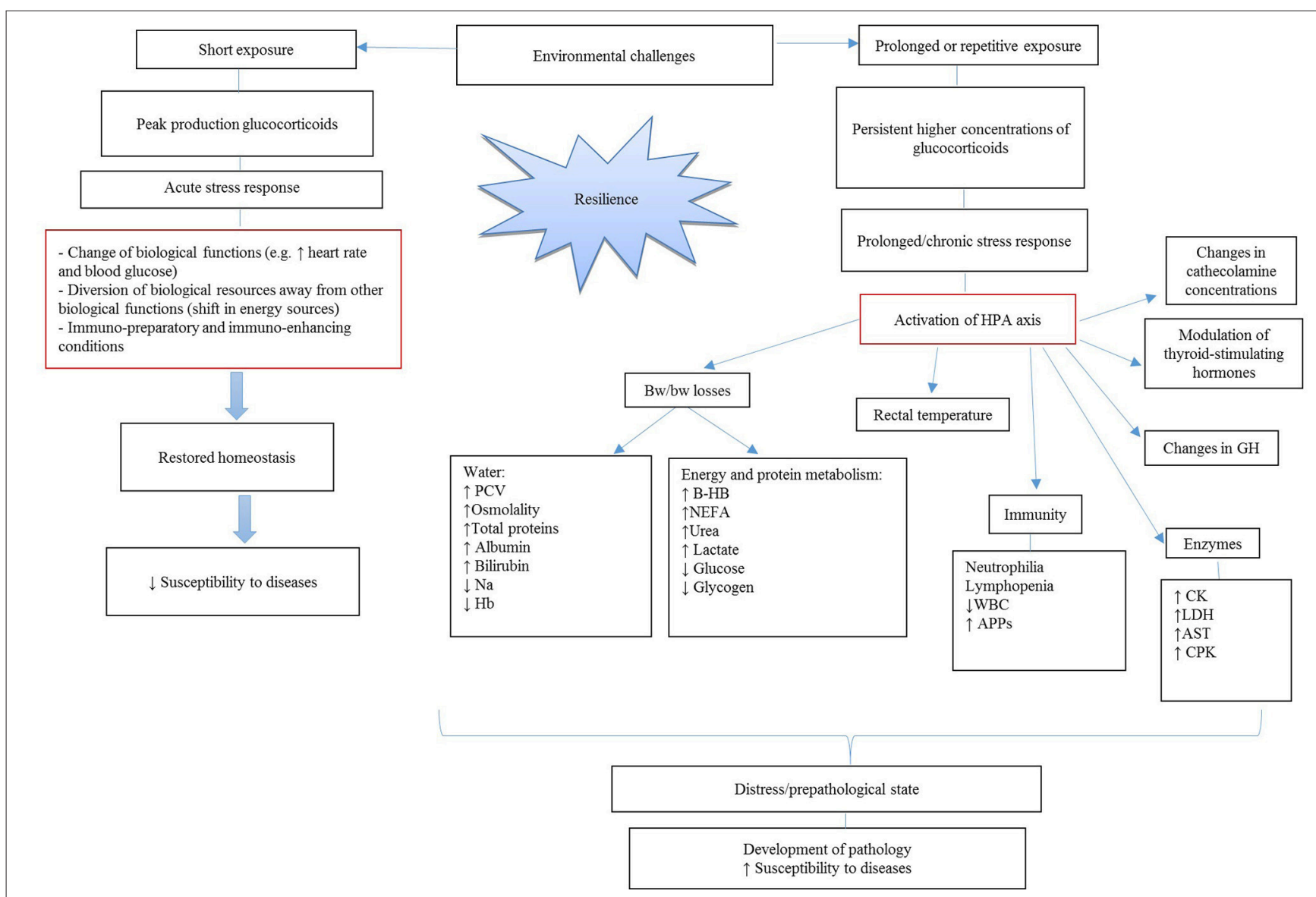

FIGURE 1 | Effects of short and long-term exposure to environmental challenges on disease susceptibility. HPA axis, hypothalamic-pituitary-adrenal axis; GH, growth hormone; BW, body weight; PCV, packed cell volume; Hb, hemoglobin; $\beta$-HB, $\beta$ - hydroxybutyrate; NEFA, non-esterified fatty acids; WBC, white blood cells; APPs, acute phase proteins; CK, creatine kinase; LDH, lactate dehydrogenase; AST, aspartate aminotransferase; CPK, creatine phosphokinase. 
about the corresponding biological mechanisms involved will be also explained. All these effects will be discussed in association with disease development in young veal calves in the first 3 weeks at the veal farm. Moreover, it will be discussed which parameters might be the most important biomarkers that could be used at on-farm arrival to predict health and welfare of calves at the veal farm. For achieving these goals, each paragraph of this review will contain a description of the physiological role of the variable of interest, how it is affected by environmental challenges, and the possible association of the variable with an ongoing disease process or later disease susceptibility. Finally, some conclusive remarks on the potential use of the variables as biomarker will be made and some advices for future studies will be given.

\section{CORTISOL}

Cortisol is a glucocorticoid hormone derived from cholesterol. Cortisol is the primary hormone involved in the stress response and is regulated by the HPA axis. The main action of cortisol consists of activating biological functions to respond to stress and restoring homeostasis after exposure to stress (44). Transportation of calves to the veal farm, as well as management of calves at the dairy farm of origin and at the collection center, are challenges that increase the activity of the HPA axis (36). A rise in plasma cortisol concentrations was often observed in transported calves and it is the main indicator of psychological/physiological stress (Figure 1) (45, 46). The increase in plasma cortisol concentrations can be transient when normal levels are restored in 1-2 days or chronic when hypercortisolemia continues for at least 4-5 days (47). Grigor et al. (31) found significantly higher concentrations of cortisol in transported 10-days-old calves (up to $25.2 \mathrm{nmol} / \mathrm{l}$ ) compared with non-transported calves (up to $16.3 \mathrm{nmol} / \mathrm{l}$ ). Bernardini et al. (48) also observed an increase in cortisol (up to $23.7 \mathrm{nM}$ ) in young calves (37 \pm 6 days of age) following transportation for $19 \mathrm{~h}$. However, cortisol concentrations were not extremely high compared to normal levels $(18.4 \mathrm{nM})$ and calves restored their basal cortisol levels within 2 days.

Aich et al. (49) found considerably higher cortisol levels the day prior to BRD infection in animals that died compared to those surviving a synergic viral-bacterial infection. However, these concentrations (150 mmol/l cortisol in serum) are indicative of the current health status of the animal and not maintained beyond that day. In all the previously mentioned studies the rise in cortisol concentrations was observed on a short-term and there was no information on chronic elevations of cortisol.

Different studies $(47,50)$ reported that prolonged high cortisol concentrations can result in increased glucose metabolism, insulin resistance, inhibition of glycogen synthase in the skeletal muscle and visceral obesity. As a consequence of these adverse health effects, the animal might be less resilient to diseases. These metabolic changes might lead to problems, including hyperglycemia, insulin resistance, glucosuria and reduced energy utilization at the end of the producing cycle at the veal farm. Moreover, changes in circulating glucocorticoids concentrations, and thus cortisol, are responsible for changes in cytokine levels and the production by leukocytes (51-53). Therefore, when calves are stressed and have high cortisol levels for a prolonged period, calves are at risk for an altered immune function (43). Figure 2 shows the pathways through which glucocorticoids affect the immune system and, thus susceptibility to diseases (43).

Cortisol, by impairing the immune functionality, might be used as biomarker for predicting future diseases. Calves with chronic hyper-cortisolemia and changes in their immune cell parameters (e.g., neutrophils, lymphocytes and acute phase proteins, APPs) might be profiled as high-risk calves. Further research is needed to establish a relationship between chronic high cortisol concentrations upon arrival at the veal farm and incidences of health and metabolic disorders during the subsequent fattening period (4-5 months). Chronic hypercortisolemia might be measured by taking repetitive blood samples, for example, in the first 2 weeks after arrival at the veal farm. Then, it should be checked whether the overall cortisol levels in serum are consistently increased during the period of blood collection. Moreover, future studies should address the relationship between chronic hyper-cortisolemia and functionality of the immune system. There is a need to clarify what type of immune cells have the greatest effects on the health of veal calves, and especially on the probability of developing respiratory or enteric diseases. All this information will provide useful data for clarifying the role of cortisol as biomarker of future diseases. However, chronic hyper-cortisolemia can only be assessed by repeated measurements. With regards to feasibility, it would be preferable to use non-invasive techniques such as collecting saliva (54) or hair (55) samples instead of blood to prevent induction of acute stress response during sampling.

\section{BODY WEIGHT (BW) AND BW LOSSES}

Measurement of BW losses, defined as the differences in BW before and after transport, is an indicator of the hydration status and/or body nutrient mobilization (e.g., fat or proteins). Environmental challenges, and especially long transport durations, are important causes of dehydration, fat mobilization, muscle protein degradation and thus loss in BW (Figure 1) (36). Therefore, BW before transport and upon arrival at the veal farm may reflect the dehydration and metabolic state of the animal. Body weight per se, is related to the condition and birth weight of the animal. Calf BW on arrival at the farm might also influence the performance of the animal in the first weeks of the producing cycle.

It has been reported that calves may lose between 3 and $11 \%$ of their BW during transport to the farm (56). Bernardini et al. (48) found that calves unloaded at the veal farm after $19 \mathrm{~h}$ transport had $6.4 \%$ BW losses compared with non-transported calves. Calves may lose BW after long transport durations because of stress coupled with fasting and mild dehydration $(57,58)$. Calves that lose more than $8 \%$ of $\mathrm{BW}$ in 1 day are depressed (clinical symptoms: skin tenting $>10 \mathrm{~s}$, eyes very sunken, dry gums and the calf lays down) and require intravenous treatment; BW losses $>14 \%$ might even lead to calf death (59). There is evidence that 


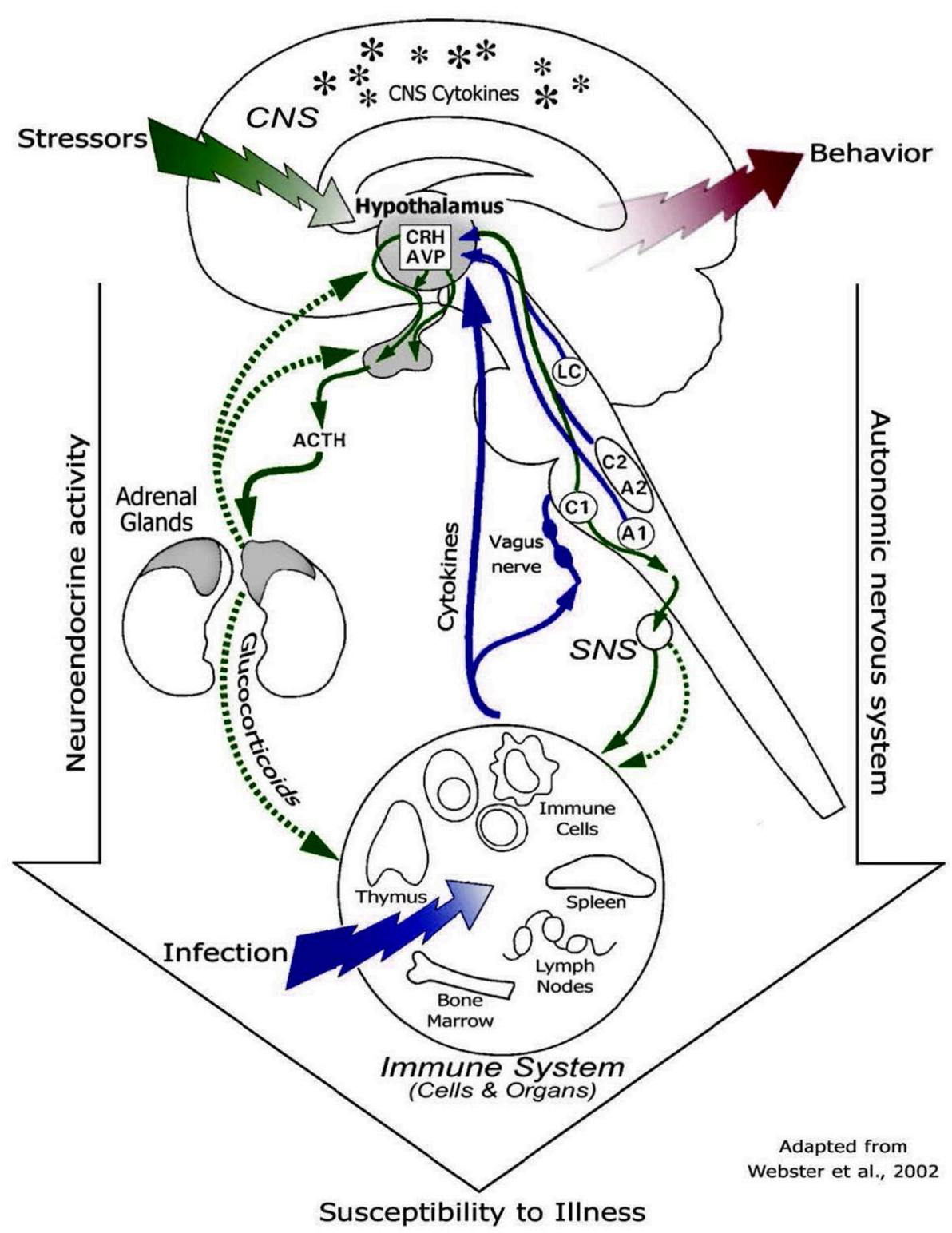

FIGURE 2 | Diagram of routes of communication between the brain and the immune system, including HPA axis, sympathetic nervous system, and cytokine feedback to the brain [๔ 2011. Oscar Vegas, Larraitz Garmendia, Amaia Arregi and Arantza Azpiroz. Originally published in "Effects of social stress on immunomodulation and tumor development" under CC BY 3.0 license. Available from Vegas et al. (43)].

BW loss is highly influenced by feeding and water provision prior to transport of calves to the veal farm $(30,48)$. Moreover, an increase in plasma protein, albumin, osmolality and packed cell volume (PCV) in calves with high BW loss, suggests that BW losses are particularly due to dehydration of calves.

Body weight losses, resulting from dehydration might reduce the adaptive capacity of the animal. According to Renaud et al. (28) the risk of mortality increases when calves are $>10 \%$ dehydrated. However, mechanisms underlying the loss of BW as a reflection of dehydration have to be further explored.

It was reported that BW at arrival is associated with the prevalence of respiratory diseases at 3 weeks upon arrival at the farm (4). As shown in Table 1, veal calves with $B W>51 \mathrm{~kg}$ had the lowest probability to develop respiratory diseases at the veal farm (adjusted $R^{2}=25 \%$ ) (4). In recent Canadian studies $(28,60,61)$ body weight of calves at arrival at the veal farm was also inversely associated with early mortality (Table 1). Other studies on feedlot cattle used mean cohort arrival body weight as a useful predictor of future diseases and health problems (6264). Lighter-weight cattle presented a higher incidence of BRD morbidity and overall mortality compared to heavier cattle (62) (Table 1).

From these findings, it can be concluded that BW might be a useful parameter to monitor and to predict the health status of 
TABLE 1 | Some associations between body weight (BW) and future risk of respiratory diseases or early mortality in different studies on cattle.

\begin{tabular}{|c|c|c|c|}
\hline References & Mean arrival BW (kg) & $\begin{array}{c}\text { Prevalence (predicted means) of respiratory } \\
\text { diseases }(\%)\end{array}$ & $P$-value \\
\hline \multirow[t]{5}{*}{ (4) } & $\leq 43$ & 7.6 & 0.004 \\
\hline & $43-47$ & 6.1 & \\
\hline & $48-51$ & 6.6 & \\
\hline & $>51$ & 2.7 & \\
\hline & BW at arrival & $\begin{array}{l}\text { Hazard ratio for early mortality }(<21 \text { days after } \\
\text { arrival at the veal farm) }\end{array}$ & \\
\hline \multirow[t]{2}{*}{ (60) } & Per 1-kg increase & 0.93 & $<0.01$ \\
\hline & BW at arrival & $\begin{array}{l}\text { Odds ratio for early mortality }(<21 \text { days after arrival } \\
\text { at the veal farm) }\end{array}$ & \\
\hline \multirow[t]{2}{*}{$(61)$} & Per pound & 0.99 & 0.03 \\
\hline & Mean arrival BW (kg) & $\begin{array}{l}\text { Incidence rate } \\
\text { ratio (IRR) for } \\
\text { BRD }^{\mathrm{a}} \text { morbidity }\end{array}$ & \\
\hline \multirow[t]{2}{*}{$(62)$} & $\begin{array}{c}272-317 \\
318-362 \\
>362\end{array}$ & $\begin{array}{l}1.08 \\
0.69 \\
0.55\end{array}$ & $<0.05$ \\
\hline & Mean arrival BW (kg) & Cumulative mortality risk for BRD & $P>\chi^{2}$ \\
\hline (63) & $\begin{array}{c}363-408 \\
318-362 \\
272-317 \\
227-271 \\
182-226 \\
<182\end{array}$ & $\begin{array}{l}0.02 \\
0.12 \\
-0.01 \\
0.04 \\
0.40 \\
0.44\end{array}$ & 0.0012 \\
\hline
\end{tabular}

${ }^{a}$ Bovine respiratory disease.

calves at the veal farm. At this stage, BW upon arrival appears to be the most reliable predictor for future diseases at the veal farm. However, it is still unclear whether lower BW values at arrival are due to lower birth weights of calves or due to substantial BW losses during transportation, or a combination of both. This should be elucidated in future research. As shown in Table 1, it seems that differences in BW in the study of Brscic et al. (4) were likely related to different factors (e.g., BW losses, age, colostrum management), whereas in the other studies on feedlot cattle the difference in BW is mainly caused by a different developmental stage of calves. Breed is another important factor that might be related to differences in BW. For example, there is an increasing demand in the veal industry for Holstein Friesian-beef breed cross breeds. Moreover, future studies should investigate whether BW losses are also predictive of the future health state of veal calves. With regards to feasibility, in case of an equal predictive value of both $\mathrm{BW}$ losses and BW, BW values are simpler to obtain than those for BW losses. In fact, for measuring BW, the animal is just weighed one time upon arrival at the veal farm, whereas in case of BW losses it is necessary to record BW before and after transportation of calves to the veal farm. Therefore, BW might be a more practical and feasible biomarker compared with BW losses. On the basis of BW values, a farmer might profile veal calves by separating putatively high-risk calves with a lower BW from the rest of animals. Then, lighter calves might receive a special daily care and management in order to avoid the spread of diseases and a lower production performance compared with healthy calves.

\section{DEHYDRATION-RELATED VARIABLES}

\section{PCV}

Part of BW losses or low BW of calves may be due to dehydration. Some specific variables may be related to dehydration, among which packed cell volume (PCV). PCV is a variable related to the number of red blood cells (RBC) in an animal. By definition, PCV is the ratio of the red blood cells to the volume of whole blood (which contains also white blood cells and plasma). PCV can be influenced by environmental challenges, such as transportation of calves to the veal farm. PCV values recorded by Knowles et al. (30) range from $39.8 \%$ in control non-transported calves to $40.8 \%$ in 24 -h transported calves. This finding was confirmed in other studies $(36,65)$ on long-term transport of young cattle. The increase in PCV can also be found in transported calves in combination with fasting of $48-72 \mathrm{~h}$. This is associated with a greater water loss during transportation as well as the stress of ADAPTING to a new environment $(36,46)$. By contrast, other studies demonstrated a decrease in PCV in animals transported 
by road $(66,67)$. After 8 -h transport, calves showed a significantly lower PCV value $(33.7 \%)$ compared with the control nontransported calves (38.2\%) (30). These results might be due to restraint and handling procedures before transport or stressors during transport (68). In fact, an increased cortisol concentration seems to move water from the rumen into the plasma resulting in a decrease in PCV values (66).

Both higher and lower PCV values might be good indicators of an ongoing disease process. Calves with diarrhea might experience excessive fluid losses that lead to higher PCV values (69). By contrast, lower PCV can be used for the diagnosis of anemia or other health problems (70).

As explained previously, PCV values can indicate the extent of dehydration of a calf on arrival at the veal farm. When a calf is dehydrated, it may experience a weight loss. Moreover, if not treated immediately, consequences of dehydration might be still visible in the first weeks at the veal farm. Therefore, the ADG and gain:feed ratio may be negatively affected in the first weeks at the veal farm (71). Seifi et al. (72) demonstrated that calves up to 14 days of age with PCV values at arrival above $44.17 \%$ were 4 times more likely to die. This was in agreement with Klee et al. (73) who observed a reduction in treatment efficacy in calves with diarrhea when PCV was above 50\%. An accurate analyses of PCV values may, therefore, provide information on calves that need to receive extra care in order to minimize body weight losses and reduction in performance due to water losses in the first weeks at the veal farm. Therefore, by identifying potentially high-risk calves with significantly higher (above 43\%) PCV values, PCV might be a reliable biomarker of diseases at the veal farm.

\section{Total Protein (TP)}

Alongside with PCV, an increase in total protein (TP) and albumin concentrations in the plasma are also measurements reflecting dehydration of the animal (74). TP is also an important indicator of the amount of colostral proteins in young calves, that is reflecting the immune state of these animals (75). This parameter can be influenced by environmental challenges, including transport duration. Bernardini et al. (48) found significantly higher plasma total protein concentrations (63.9 g/l) in young calves ( $37 \pm 6 \mathrm{~d}$ of age) subjected to 19 -h transport at their arrival at the veal farm compared to non-transported calves.

Values of TP are important, especially for predicting mortality in the first weeks at the veal farm (76). Naylor et al. (77) observed a significantly lower mortality in the first 5 weeks of age in calves with $T P>6.1 \mathrm{~g} / \mathrm{dl}$. Moreover, Rea et al. (78) reported that calves with $\mathrm{TP}<4.5 \mathrm{~g} / \mathrm{dl}$ had a higher risk of dying in the first weeks at the farm. By contrast, other studies suggested that TP cannot be considered a reliable indicator of diseases and mortality in calves $(75,79)$. Hence, TP is difficult to interpret in terms of risks for calf health and performance. Higher levels of TP may indicate higher levels of colostral proteins, which is a positive sign. However, high levels of TP may also be indicative of dehydration, which is a negative sign.

\section{Albumin}

Albumin is the major negative acute phase protein (APP). During the acute phase response, albumin concentrations decrease for the synthesis of positive APP. Hence, albumin is a main source of amino acids that animals can use when necessary and it plays an important role in plasma osmotic pressure (80). As shown by the study of Knowles et al. (34), albumin concentrations increased from 39.8 to $43.1 \mathrm{~g} / \mathrm{l}$ in calves subjected to transport as a result of dehydration.

Albumin might be used not only as a measure of dehydration, but also as a prognostic marker or to assess the severity of diseases (81-83). For example, low albumin concentrations in dairy cattle were associated with uterine infections (83) and inflammation $(84,85)$.

Limited research (79) has been done in young veal calves, especially on the predictive value of albumin. The available evidence suggests both high and low albumin values may indicate a risk. Thus, it is necessary to understand to what extent an increase or a decrease in albumin values is associated with diseases or future health problems in veal calves.

\section{Bilirubin}

Bilirubin is a product of heme degradation and it functions as antioxidant (86). This variable is influenced by environmental challenges. Mormede et al. (33) found an increase in plasma bilirubin $(5-10 \mu \mathrm{mol} / \mathrm{l})$ in young calves after being transported to the veal farm; this increase was more pronounced in calves subjected to long-transport duration.

The higher concentrations of this variable might be determined by an increased dehydration of the animals subjected to transport. However, their increase could also be related to a compromised health status of calves. Higher bilirubin concentrations were indicators of impaired hepatic function in dairy cows in a negative energy balance situation and with inflammation (87). Extrapolated to calves, this would imply that calves might experience metabolic changes in the liver as a consequence of stress during transport. However, until now no studies on veal calves examined bilirubin as a possible biomarker of ongoing health problems or predictor of future diseases.

\section{Electrolytes and Minerals}

Electrolytes and minerals are responsible for maintaining a good water balance and for normal functioning of essential biochemical processes in the animal body (88). Calves may experience changes in their electrolyte and mineral balance when they are transported under stressful conditions (36). Cattle have a substantial blood buffering ability but during transport they show plasma electrolyte and mineral changes, including sodium, potassium, chloride, calcium and magnesium (89-91). In a state of stress, there are higher concentrations of calcium in the extracellular fluids that lead to a greater contractility of skeletal and heart muscles (92). Moreover, Grigor et al. (93) found significantly higher plasma sodium concentrations after $5.25 \mathrm{~h}$ of transport in fed calves $(136 \mathrm{mmol} / \mathrm{l})$ compared with the unfed controls $(133 \mathrm{mmol} / \mathrm{l})$, but it is unclear what this relatively small difference in plasma sodium means.

Changes in sodium values might be useful as indicators of calf diarrhea. Calves with diarrhea generally have significantly lower concentrations of serum sodium than healthy controls (94). This is in accordance with Maach et al. (95), who found that 
calves with acute diarrhea had lower plasma concentrations of sodium and chlorine $(131.2 \pm 6.8 \mathrm{mmol} / \mathrm{l}, 95.6 \pm 6.9 \mathrm{mmol} / \mathrm{l}$, respectively) in their serum compared with healthy calves (140.0 $\pm 9.9 \mathrm{mmol} / \mathrm{l}, 103.3 \pm 6.9 \mathrm{mmol} / \mathrm{l}$, respectively). Calves with diarrhea can also have hyperkalemia as a consequence of the dysfunction of the $\mathrm{Na}+/ \mathrm{K}+$ ATPase (96).

Seifi et al. (72) found that serum potassium concentrations $>5.63 \mathrm{mEq} / \mathrm{l}$ in calves with diarrhea were associated with 4 -fold increase risk of mortality. Moreover, hyper-kalemia $(K>5.8$ $\mathrm{mmol} / \mathrm{l}$ ) can cause severe dehydration and can be associated with changes in body temperature homeostasis (97). As a consequence of the alteration of physiological mechanisms, calves might be more predisposed to develop severe diseases.

\section{Osmolality}

Transported calves may also experience changes in their plasma osmolality, which is an indicator of the osmotic pressure of the plasma (30, 31, 34, 98). Knowles et al. (30) observed the highest values of plasma osmolality in young calves transported for $24 \mathrm{~h}$ (278 mOsm $/ \mathrm{kg}$ ) compared with control calves $(275.4 \mathrm{mOsm} / \mathrm{kg})$. These results indicated that calves become more dehydrated when they are subjected to a longer transport duration. The effect is likely to be more pronounced when calves are deprived of food and water prior to transport (30). Osmolality is, therefore, an important indicator of the hydration status of the animal $(31,99)$.

The dehydration status of a calf might be related with an increased likelihood to develop diseases at the veal farm (27). Griffin et al. (100) assigned calves suffering from dehydration, combined with malnourishment and exhaustion to a high-risk class, with a greater probability of becoming sick. Moreover, Renaud et al. (28) reported that the degree of dehydration at arrival is an important predictor of mortality in the first 21 days after arrival at the veal farm.

\section{Hemoglobin}

The white veal calf industry has always raised calves with a low hemoglobin $(\mathrm{Hb})$ status. $\mathrm{Hb}$ acts as a transporter of oxygen from the lungs to the tissues and as a transporter of carbon dioxide from the tissues back to the lungs. This function depends on the molecular structure of hemoglobin, which contains four heme groups, each with a central iron molecule (101). Due to the specific diet based on milk replacers and solid feeds with low iron content for several weeks, calves might develop anemia, which has a negative impact on growth and feed conversion ratio $(102,103)$. However, in the interim period or at the end of the fattening cycle, lower $\mathrm{Hb}$ concentrations are desirable because they are associated with low myoglobin and pale meat (104).

Nowadays, the industry pays more attention in maintaining $\mathrm{Hb}$ values a certain range. In the Netherlands, all calves are monitored within the first 2 weeks upon arrival at the veal farm and calves with $\mathrm{Hb}$ levels below a certain threshold are treated with supplemental iron. Another systematic monitoring is done between 12 and 14 weeks of fattening (105). However, outside these moments blood $\mathrm{Hb}$ (or iron) values of veal calves are usually not systematically monitored, and it is likely that some animals may develop subclinical anemia. Therefore, measurement of $\mathrm{Hb}$ can be used to assess on-farm anemic state of calves.
$\mathrm{Hb}$ might also be used as predictor of diseases in calves. As a consequence of their anemic status, both health and robustness of calves are affected and calves are more vulnerable to diseases (106). In animals iron deficiency (with blood Hb lower than $6.0 \mathrm{~g} / \mathrm{dl}$ ) is known to affect both humoral and cell-mediated immunity (107). As a consequence of the impaired immune functionality, calves might be more susceptible to infectious diseases. Steinhardt and Thielscher (108) observed that the growth of calves with low $\mathrm{Hb}$ values at arrival at the veal farm was lower compared with calves with normal range of $\mathrm{Hb}$. Gygax et al. (103) reported also that iron deficiency can lead to higher infection rates, especially in the respiratory and the gastrointestinal tract. Therefore, these findings suggested that $\mathrm{Hb}$ values upon arrival at the veal farm may be good biomarkers for predicting calf health and welfare status after transportation to the veal farm; lower $\mathrm{Hb}$ levels are indeed more likely to be associated with a major risk of poor welfare and a higher incidence of diseases $(109,110)$. Hence, the deliberate attempt by the veal industry to avoid anemia in young calves is through the administration of iron.

\section{Conclusions on Dehydration-Related Variables}

All variables discussed in this paragraph are correlated with dehydration and PCV seems to be the most suitable and practical on farm biomarker. However, their association with disease status may not only be based on dehydration status, but also on factors like stress, colostrum intake, acute phase proteins and antioxidative status. Therefore, more research on correlations among these variables and the occurrence of respiratory or enteric diseases would be necessary to perform. Based on reasearch currently reviewed, it can be disputed which dehydration related variable is most reliable as on-farm biomarker.

\section{ENERGY AND PROTEIN METABOLISM}

\section{Lactate}

Besides dehydration, losses of glycogen, protein and fat may affect metabolism and future diseases in calves. In order to understand the consequences of body glycogen, protein and fat mobilization on future health problems, different variables can be measured. Calves may experience a rise in lactate levels, especially after a long-distance transport (111). This might be the result of the degradation of muscle glycogen due to stress or exhaustion, that causes the liberation of catecholamines and a rapid glycogenolysis and gluconeogenesis (112).

In a study in cattle (49), L-lactate levels were higher prior to viral infection. Moreover, higher L-lactate values are related with higher risk of disease occurrence, like displaced abomasum and volvulus, in different animal species (113-115), and especially in calves with diarrhea (116-118). A positive correlation $(r=$ 0.55 ) between acidosis (determined by L-lactate) and dehydration (determined by PCV) was found in calves with diarrhea (119).

Associations between lactate concentrations and measures of later calf health were also reported by different studies, with contradictory results. Aich et al. (49) found that calves which 
survived had significantly higher lactate concentrations prior to a viral infection compared to calves which died (Figure 3A). In contrast, in a study by Coghe et al. (120), relatively high lactate levels $(>4 \mathrm{mmol} / \mathrm{l})$ in BRD affected calves were associated with an increased likelhood of mortality in the following $24 \mathrm{~h}$.

Buczinski et al. (121) reported that for each 1-unit increase of the log-lactemia there was an increase of 36.5 in hazard of dying of BRD. In general, enhanced L-lactate levels are associated with hypoxemia (122) and /or endotoxemia (123) that characterizes ongoing BRD episodes. Lower oxygen levels in the lungs are known to reduce macrophage activity, so pathogens can multiply at higher rates. As a result, the animal might be more exposed to the action of pathogens and it might develop respiratory diseases (124).

Thus, L-lactate might be considered a biomarker for assessing an ongoing disease process, such as pneumonia (based on clinical signs and hypoxemia) and for predicting death of clinically ill calves within $24 \mathrm{~h}$. However, contradictory results merit further research into the use of L-lactate and lactate as biomarkers for respiratory diseases in young veal calves. At the same time, practical application of this biomarker might be highly feasible, because it can be measured by a portable analyser at a relatively low cost and results are available in $60 \mathrm{~s}$ (121).

\section{$\beta$-Hydroxybutyrate ( $\beta$-HB) and Non-esterified Fatty Acids (NEFA)}

Environmental challenges, as depicted in Figure 1, are the main cause of mobilization of fat resources in young calves (125). The mobilization of the adipose tissue is associated with an increase in plasma concentration of free fatty acids and $\beta$-hydroxybutyrate $(\beta-\mathrm{HB})(31,62)$. Transportation as well as fasting increase the energy demands of young veal calves, so animals experience hypoglycaemia and a lack of C3 units in mitochondria $(126,127)$. As a result, C2 units accumulate in the mitochondria and are removed via production of ketone bodies. Bernardini et al. (48) found an increase in NEFA and $\beta$-HB above the normal values $(0.13-0.20 \mathrm{mmol})$ at the end of transportation. These results were in accordance to Radostits et al. (128) and Knowles et al. (30), who found concentrations up to $0.46 \mathrm{mmol} / \mathrm{l} \beta$ - HB and 0.55 $\mathrm{mmol} / \mathrm{l} \mathrm{NEFA}$ in young calves (between 1 and 2 weeks of age) transported for $24 \mathrm{~h}$. Moreover, the increase in NEFA and $\beta$-HB appears to be greater in unfed calves compared with calves that receive feeding prior to transport (30).

$\beta$-hydroxybutyrate and NEFA values represent useful indicators of calf energy balance and of body fat mobilization during and immediately after transportation of calves to the veal farm (34).

Changes in energy balance of calves might be associated with changes in biochemical, endocrinological and metabolic pathways underpinning production, maintenance of health and ability to cope with disease challenges (129). According to Wilson et al. (76) and Renaud et al. (28) many male calves entering the veal facility are experiencing suboptimal energy status and low body fat cover. A suboptimal energy status and higher levels of NEFA in the serum facilitate disease development and suppress the immune function (130). Future studies should continue to investigate the complex link between the immune system responses associated with increase in blood NEFA levels and $\beta$-HB concentrations. So far, associations between negative energy balance, NEFA and $\beta$-HB have only been studied in adult dairy cattle (131), and there is little information available on the effects of these parameters on disease incidence later in life of young veal calves. Renaud et al. (28) reported that NEFA and $\beta$-HB might be used as markers of the energy status, but in this study they were not associated with morbidity or mortality. However, this study was based on short transport duration, thus more research is needed to explore the effects of long transport duration on energy status.

\section{Urea}

Plasma urea concentrations might also be affected by environmental challenges (Figure 1), including transportation (36). Higher plasma urea values are indicators of protein and nucleic acids breakdown in the muscles as a result of increasing cortisol concentrations and prolonged fasting (29). Knowles et al. (30) observed that young calves ( $<1$ month old) receiving 11 of glucose/electrolyte solution during transport showed lower urea $(3.58 \mathrm{~g} / \mathrm{l})$ values after $24 \mathrm{~h}$ transport compared with the control group $(4.50 \mathrm{~g} / \mathrm{l})$. In another experiment, these authors found higher plasma urea values in calves subjected to the same transport duration $(5.61 \mathrm{~g} / \mathrm{l}$ in $24 \mathrm{~h}$ ) when not being fed during the journey compared with control calves (5.34 g/l) (30). These results suggest that feeding during long transport durations may help calves in reducing muscle protein degradation during their journey to the veal farm.

Urea concentrations might be used to assess the acute disease state of calves. In fact, protein catabolism, growth retardation and excessive nitrogen excretion might be the consequences of an ongoing disease process (132). However, additional information is needed to understand the underlying physiological and immune mechanisms involved in disease incidence.

Fayet and Overwater (133) analyzed several biochemical parameters of newborn calves and associated these variables with future survival of calves. Among these variables, blood urea concentration was a reliable predictor of survival rate of calves with $80 \%$ accuracy. The authors found significant differences in average urea concentrations between surviving calves (68.5 $\pm 35.7 \mathrm{mg} / \mathrm{dl}$ ) and dead calves (141.4 $\pm 78.0 \mathrm{mg} / \mathrm{dl})$. Seifi et al. (72) conducted another study in young calves (up 14 days of age) with diarrhea. The authors aimed to investigate the associations between serum biochemical variables and future survival of calves. The results of this study showed that blood urea nitrogen (BUN) concentrations can be used as valid prognostic indicators. Calves with diarrhea were 5.6 times more likely to die when their BUN concentrations were higher than 13.07 mmol/l. Correspondingly, Klee et al. (73) also demonstrated that the efficacy of treatment in calves with diarrhea was lower when BUN concentrations were above $28.56 \mathrm{mmol} / \mathrm{l}$. However, given these differences in threshold levels, additional research is necessary before urea could be used in practice as biomarker. 

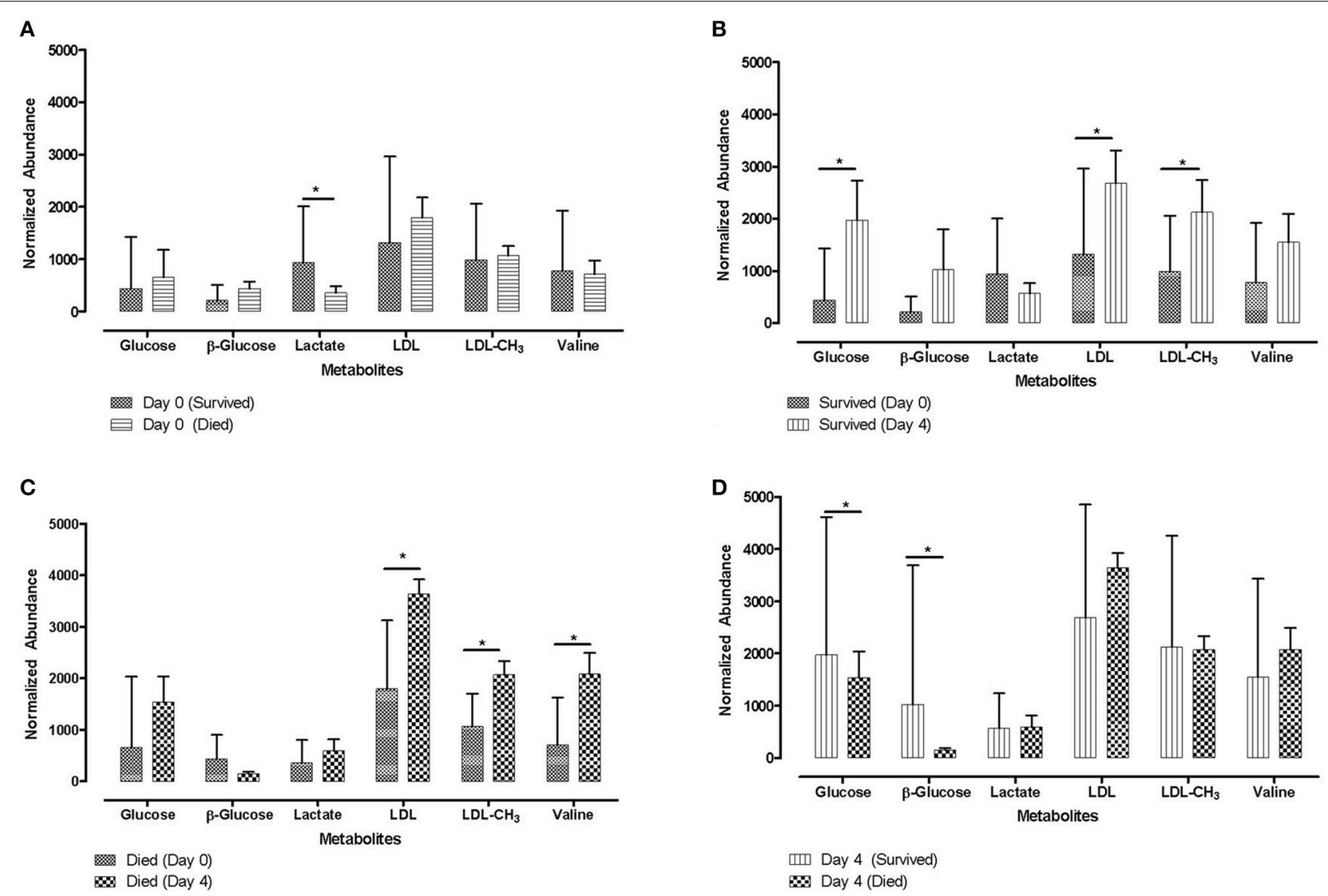

띠 Day 4 (Survived) 8 Day 4 (Died)

FIGURE 3 | Metabolite profiles for animals that survived or died. Letters (A) to (D) represent four different situations depending on metabolite data derived from samples collected on Day 0 (prior to viral infection) and samples collected on Day 4 (post BHV-1 infection). Bar charts for distribution profile of identified metabolites from ${ }^{1} \mathrm{H}-\mathrm{NMR}$ studies for animals that died or survived following synergic viral-bacterial infection are shown in bar chart form. Error bars shown indicate 1-standard deviation. Metabolite IDs are shown on the x-axis [The publisher for this copyrighted material is Mary Ann Liebert, Inc., publishers Aich et al. (49)]. *Significant differences $p<0.05$.

\section{Glucose}

As indicated in Figure 1, higher cortisol and glucocorticoids concentrations following transportation or other challenges might cause changes in plasma glucose. Previous studies on changes of plasma glucose concentrations in transported calves revealed different outcomes. At one hand, some authors (74, 134-136) found higher plasma glucose levels which may be a result of elevated stress levels that activate the hypothalamicpituitary-adrenal axis (HPA). On the other hand, Trunkfield and Broom (137) showed that calves experienced hypoglycaemia after transportation, which may be a consequence of the activation of HPA axis, higher glucocorticoids and catecholamine concentrations and because of the higher energy requirements during the journey and restriction of food and water intake before, during and after transport (65). Mormede et al. (33) reported a decrease of 38 and 54\%, respectively in plasma glucose level in young calves after short and long transportation. Alteration in plasma glucose concentrations are highly influenced by the time and plane of feeding before and after transportation of calves (29). Differences in this respect may explain the great variability among studies on glucose in calves after transport. On a short term and shortly after feeding, higher cortisol concentrations can cause an increase in plasma glucose, whereas on a longer term, glycogen stores can be depleted and thus blood glucose concentration is lower.

Studies in cattle reported that a disease challenge initially resulted in hyperglycemia, followed by a period of hypoglycemia $(138,139)$. Montgomery et al. (140) found lower plasma glucose levels than normal $(5.3 \pm 0.07 \mathrm{mmol})$ in an experiment with heifers treated for BRD. Moreover, hypoglycemia was found to be related to neonatal calf diarrhea and endotoxaemia in calves (141). However, more research should be done to investigate the association between hypoglycemia and acute diarrhea in veal calves.

Cusack et al. (142) found that low plasma glucose levels in calves on arrival at the feedlot were associated with a greater probability of developing severe BRD at later stages. This is in accordance with another study on steers transported for $12 \mathrm{~h}$, in which low blood glucose levels after transport increased the incidence of morbidity and mortality in these 
animals in the following 56 days (71). Additionally, in the study of Trefz et al. (141) calves with severe hypoglycemia had a lower survival rate $(20.6 \%)$ compared with calves with normal plasma glucose concentrations (74.0\%). Mormede et al. (33) also reported that hypoglycaemia after transport in combination with lower growth rate in the first weeks after transport may even affect performance at later stages. Accordingly, Aich et al. (49) demonstrated with metabolomic analyses that higher glucose concentrations in calves of 6 months of age, following a viral BRD infection predicted survival of the animals. Against this background, several studies showed the potential of glucose as important predictor. Therefore, lower glucose concentrations might be used as on-farm biomarker of future diseases in veal calves.

\section{Body Temperature}

Temperature homeostasis is important in order to guarantee the functionality of the main physiological mechanisms in the animal body. Young calves have a limited ability to regulate their body temperature, especially during transportation (143, 144). According to Hemsworth et al. (144), the thermal comfort zone of young calves is between 13 and $26^{\circ} \mathrm{C}$, and they are sensitive to both heat and cold stress (145). Elmer and Reinhold (146) observed that young calves up to 6 weeks of age are the least tolerant to high ambient temperature $\left(35^{\circ} \mathrm{C}\right)$ compared to older animals, especially during long journeys. Changes in rectal temperature can be caused by acute or chronic secretion of catecholamines and glucocorticoids (147). In case of acute stressors, such as handling and loading procedures prior to transport, rectal temperature can increase as a result of peak production in glucocorticoids and cathecolamines (147), whereas, prolonged transport, can decrease rectal temperature to normal temperature (148).

Garcia et al. (149) classified calves with pneumonia based on rectal temperature $\geq 39.5^{\circ} \mathrm{C}$ accompanied by clinical signs of respiratory disease (e.g., mucopurulent nasal discharge, cough, increased respiratory rate). McGuirk and Ruegg (150) also reported that rectal temperature higher than $39.4^{\circ} \mathrm{C}$ for two successive days in combination with a slower, lower or lack of milk intake are indicators of diseases. Particularly, rectal temperatures $>41^{\circ} \mathrm{C}$ are associated with pneumonia (150). However, as reported by Galyean et al. (151), rectal temperature might be influenced by other factors as well, including processing order, crowding, ambient temperature and humidity. These factors should be considered when assessing animal performance and, especially BRD incidence, on the basis of rectal temperature.

Grigor et al. (31) found a positive correlation $\left(r_{s}=0.649\right.$, $P<0.01$ ) between rectal temperature of young calves during the first week after transport and first week post-transport clinical respiratory disease score (points from 0 to 3, and greater scores were associated with a worse health status). Higher rectal temperatures in transported calves seemed to indicate a greater clinical response to either BHV-1 inoculations or to other infections. Calves might also experience hypothermia, which might be considered as an adaptive response related to posttransport severe dehydration and hypoglycemia. Hypothermia might cause impairment of the $\mathrm{Na}+/ \mathrm{K}+$-ATPase, which is temperature dependent, and as a result animals might be more susceptible to diarrhea or other health problems (152).

Collectively, these findings show simple associations between rectal temperature and current health status of calves but not a clear predictive value of rectal temperature. However, both high and low rectal temperature might be associated with future health problems; future studies could investigate whether the negative effects are more pronounced in relation to high or low rectal temperature. With regards to feasibility, measurement of rectal temperature is a very easy, quick and non-invasive approach, thus it can be used by farmers on a frequent basis to check the health state of calves.

\section{IMMUNITY}

\section{Leukocyte Count and Other Immune Responses}

As shown in Figure 1, environmental challenges affect circulating glucocorticoids (increase in cortisol levels) in calves. As a consequence of stress-driven higher concentrations of stress hormones, the immune system might be affected. On the one hand, acute stress might result in immuno-preparatory conditions, by helping the animal to reinforce its defense against pathogens; on the other hand, long-term exposure to stress might have immunosuppressive effects by making calves less resilient to diseases (153). Therefore, in case of chronic stress, the functionality of the immune system might be impaired and calves might have changes in number of leukocytes, neutrophils in the peripheral circulation and other immune cells $(46,154)$. An increase in neutrophil and mononuclear cell ratio (N:M) was reported $(155,156)$. An increase in number of neutrophils was also reported $(153,154)$, but results vary among studies and other authors showed the contrary (48). Moreover, white blood cells (WBC) decreased after transportation (112).

These changes in different immune parameters in the long-term might indicate an immuno-suppressive effect and they might affect the adaptive capacity of the animal to the environmental circumstances. Due to a low functionality of defense immune mechanisms, the animal might have a reduction in performance, weight gain and an increase in susceptibility to diseases (especially respiratory diseases, such as BRD) (154, $157,158)$. Lower immunoglobulin (Ig) concentrations, especially IgG, of calves upon arrival at the farm was also reported and may contribute to a decreased resilience of calves to diseases (33). Pardon et al. (79) reported that concentrations of immunoglobulins (Ig) upon arrival at the farm, which are dependent on colostrum intake, may serve to predict BRD hazard in veal calves. Calves with Ig $<7.5 \mathrm{~g} / \mathrm{l}$ have a greater probability of dying in the first weeks at the farm. However, no relationships were found between Ig concentrations and neonatal calf diarrhea. Interestingly, Renaud et al. (28) recently demonstrated that, similar to IgG, also greater concentrations of cholesterol were associated with lower risk for mortality in the first 21 days at the veal farm. Although this association could have multiple explanations, it was argued that cholesterol could be used as a marker of colostrum intake. 
Overall, it could be concluded that measures of immunocompetence may be important predictors of later life performance, health and welfare. However, it is unclear which immunological variable or set of variables on-arrival at the veal farm would be the best predictor and thus suitable as biomarker.

\section{Acute Phase Proteins (APPs)}

Acute phase proteins (APPs) are proteins synthesized in the liver. The release of APPs in the bloodstream is induced by cytokines in response to many stressors, including transportation (80). Cytokines are produced by cells of the innate immune system (e.g., macrophages, monocytes) and function as messengers between the local site of injury and the hepatocytes producing APPs $(85,159)$. APPs exert defensive roles against pathological damage, they are responsible of restoring the homeostasis and they regulate different stages of inflammation (80). Therefore, APPs can be considered as biomarkers of stress and immunity (154).

An increase in APPs is observed in animals with diseases, thus high levels of APPs might be used as quantitative measure for identifying sick calves (160). In calves with diseases, the main changes in circulating APPs involve serum amyloid A (SAA), haptoglobin $(\mathrm{Hp})$, lipopolysaccharide binding protein (LPB), fibrinogen $(\mathrm{Fb}), \alpha$-1-acid glycoprotein (AGP) and lactoferrin (154). Gånheim et al. (161) indicated a threshold to distinguish between healthy and calves with diseases (age 9-18 weeks), including $0.13 \mathrm{~g} / \mathrm{l}$ for $\mathrm{Hp}, 25.6 \mathrm{mg} / \mathrm{l}$ for SAA and $6.45 \mathrm{~g} / \mathrm{l}$ for fibrinogen. Calves with a clinical or subclinical infection showed prolonged higher APPs concentrations than healthy calves (154). Godson et al. (162) showed that higher concentrations of Hp were associated with severe bacterial respiratory infections in cattle $\left(r^{2}=0.481\right)$. Angen et al. (163) and Hajimohammadi et al. (164) used Hp to identify calves with pneumonia and diarrea, respectively. Moreover, Tothova et al. (165) reported that the increase in some APPs levels (Hp and SAA) was associated not only with acute diseases of the respiratory tract, but also chronic cases $(P<0.01)$. The magnitude and the duration of the acute phase response reflect the severity of the infection (166-168).

Changes in APPs levels can be used not only as a measurement for early diagnosis and prognosis or for assessing the severity of diseases but also as predictors (81-83). Different studies suggested that Hp might be the most useful APP for predicting diseases and for discriminating between diseased and healthy calves due to the higher sensitivity in detecting diseases (163, 169,170 ). Higher levels of Hp (more than $0.13 \mathrm{~g} / \mathrm{l}$ ) in the first week of life were reported to be related with an increased odds ratio of future treatment for $\mathrm{BRD}$ [odds ratio $(\mathrm{OR})=2.66 ; P$ $=0.048]$, treatment for other diseases $(O R=12.59 ; P<0.001)$ and death $(O R=8.67 ; P=0.001)(160)$. In contrast, SAA might be a less suitable predictor of health problems due to its higher sensitivity to stimuli other than diseases, such as stress $(81,171,172)$. Therefore, higher values of acute phase proteins, especially $\mathrm{Hp}$, might act either as indicators of an ongoing disease process or as predictors of diseases, thus they might be suitable as biomarkers.

\section{ENZYMES}

Along with changes in immune functionality, transportation of calves at the veal farm and handling procedures are the main cause of other changes in blood plasma, including higher levels of creatine kinase (CK), creatine phosphate kinase (CPK), lactate dehydrogenase $(\mathrm{LDH})$ and aspartate aminotransferase (AST) (36). These enzymes play a significant function in energy homeostasis of tissue cells and they ensure a constant ATP levels in the cells (173). Changes in enzyme concentrations may occur due to physical and psychological challenges during transportation, which disrupt the homeostasis and, as a consequence, the metabolism of calves (174-176). In particular, higher plasma concentrations of CK, CPK and AST are associated with tissue damage, poor muscular tissue reperfusion, hypoxia and fatigue, and an increased permeability of muscles membrane following handling procedures and transport stress $(65,176-$ 178).

Changes in plasma enzymes concentrations might function as indicators of tissue damage in diseased animals (179). However, information on the relationships between these enzymes and future diseases is lacking in calves and cattle. In human patients, CK concentrations are useful for the evaluations of disorders involving damage to the myocardium, skeletal muscle and central nervous system (180). Moreover, evaluation of blood values of this enzyme might be useful to discriminate between high-risk new-born infants and low-risk new-born (180). In other studies in humans, an increase in blood LDH values seemed to be an important indicator of lung damage, pulmonary endothelial cell injury or airways problems $(181,182)$. Additionally, AST is strongly related with hepatic function, thus higher AST concentrations may indicate liver problems (183). Values of AST are also assessed together with $\mathrm{CK}$ values for diagnosis of muscle damage (99). An increase in CK, LDH and AST on arrival of calves at the veal farm was also reported compared with pre-transport values $(32,33,184)$. It can be speculated that, as in humans, higher values of these enzymes in veal calves might be associated with health problems, diseases and muscle damage. However, higher levels of these enzymes could also be positive indicators of restored homeostasis after transport or other challenges. In fact, when calves are stressed, they might try to restore their homeostasis by changing several physiological processes, including the enhancement of CK, LDH, and AST.

\section{CONCLUSIONS AND FUTURE PERSPECTIVES}

Among all variables listed in this review, there are some that seem to be good predictors of future diseases because there is information available from published studies. These variables include PCV, BW, lactate, glucose, Ig and Hp. Other variables, including $\mathrm{Na}$, osmolality, neutrophils and enzymes seem to be just indicators of ongoing diseases but they do not show any concrete association with future diseases. Existing literature suggests that variables such as cortisol, albumin, bilirubin, $\mathrm{K}, \mathrm{Hb}$, BW loss, $\beta$-HB, NEFA, urea and rectal temperature may act as 
potential biomarkers. However, due to limited data, more studies are needed to confirm their association with future diseases. Furthermore, as already indicated, different parameters may be correlated. In the study of Turkson and Ganyo (70), Hb was positively correlated with PCV vales $\left(R^{2}=0.5504\right)$. Moreover, the authors suggested to use the simplified relationship of $\mathrm{Hb}$ $(\mathrm{g} / \mathrm{dl})=(0.3 \mathrm{PCV})+3$ to estimate $\mathrm{Hb}$ concentration from PCV in cattle. PCV measurement is a simple and cheap approach and therefore it can be used by farmers to assess anemic status and dehydration of calves at the veal farm. Blood collection for $\mathrm{Hb}$ analyses is performed on routine basis in the veal industry. Different blood samples are collected at specific time points throughout the rearing period. We suggest that these blood samples may also be used to obtain potential biomarkers, including PCV.

With regards to $\mathrm{Hp}$, concentrations of this $A P P>0.13$ $\mathrm{g} / \mathrm{l}$ in combination with higher rectal temperature, increased nasal score and calf depression are indicators of respiratory diseases such as pneumonia (160). Overall, generation of big data sets including all the afore mentioned variables would allow to establish correlations between all different parameters. With these datasets, it would be possible in future studies not only to describe associations between variables, but also to find their predictive value for diseases in later life in veal calves. Eventually, the performance of promising biomarkers of health and performance of veal calves should also be investigated in terms of quantitative test characteristics such as sensitivity and specificity.

There are other new alternatives that could be considered to obtain more information on these variables and thus improve on farm health problems. A solution might be the use of post-genomic technologies of transcriptomics, proteomics and metabolomics in order to develop new biomarkers for detecting

\section{REFERENCES}

1. Pardon B, Catry B, Boone R, Theys H, De Bleecker K, Dewulf J, et al. Characteristics and challenges of the modern Belgian veal industry. Vlaams Diergen Tijds (2014) 83:155-63. Available online at: http://hdl.handle.net/ 1854/LU-5702237

2. Brown R, Claxton R. Global veal market overview presentation. In: Proceedings of the 5th International Veal Conference (2011), (Noordwijk ann Zee).

3. Hulbert LE, Moisa SJ. Stress, immunity, and the management of calves. $J$ Dairy Sci. (2016) 99:3199-216. doi: 10.3168/jds.2015-10198

4. Brscic M, Leruste $H$, Heutinck LF, Bokkers EA, Wolthuis-Fillerup $\mathrm{M}$, Stockhofe $\mathrm{N}$, et al. Prevalence of respiratory disorders in veal calves and potential risk factors. J Dairy Sci. (2012) 95:2753-64. doi: 10.3168/jds.2011-4699

5. Tao S, Dahl GE. Invited review: heat stress effects during late gestation on dry cows and their calves. J Dairy Sci. (2013) 96:4079-93. doi: $10.3168 /$ jds.2012-6278

6. Warriss PD. The transport of animals: a long way to go. Vet J. (2004) 168:213-4. doi: 10.1016/j.tvjl.2003.10.002

7. Autio T, Pohjanvirta T, Holopainen R, Rikula U, Pentikainen J, Huovilainen A, et al. Etiology of respiratory disease in non-vaccinated, nonmedicated calves in rearing herds. Vet Microbiol. (2007) 119:256-65. doi: 10.1016/j.vetmic.2006.10.001

8. Adenkola AY, Ayo JO. Physiological and behavioural responses of livestock to road transportation stress: a review. Afr J Biotechnol. (2010) 9:4845-56. diseases $(185,186)$. So far, only a limited number of postgenomic strategies were applied in veterinary research (187), but their use is of growing interest in animal studies (188). Transcriptomics might be used for detecting and genotyping animal pathogens and for studying gene mutation in case of diseases $(188,189)$. Within this field, DNA microarrays and analysis of gene expression are interesting tools for the identification of potential biomarkers of future diseases (185, 188). Proteomics might be a useful approach in biomarker discovery by studying protein component of a cell, tissue and organism (188, 190). Several techniques have been adopted in proteomic studies and quantitative proteomic strategies are developing with the aim to be applied in biomarker research. For instance, Aich et al. (49) analyzed the associations between apolipoprotein $\mathrm{AI}$ and haptoglobin with the risk of developing respiratory diseases in cattle. Metabolomic studies focus on low molecular weight metabolites and might be used to investigate pathophysiological processes of animal diseases (191, 192). Aich et al. (49) used, for example, lactate and glucose analyses to predict BRD outcome in cattle. Overall, post-genomic technologies are becoming more accepted in veterinary studies, but due to many problems related to their feasibility, cost and practicality the use of these technologies in practice is still limited. Therefore, further research in these fields is needed to identify biomarkers by using more practical and feasible solutions that can be applied in routine clinical practice.

\section{AUTHOR CONTRIBUTIONS}

FM wrote the review (main body) and $\mathrm{HvdB}, \mathrm{BK}$, and $\mathrm{KvR}$ contributed during the discussion and reviewed the preliminary versions of the manuscript.

9. Van De Water G, Verjans F, Geers R. The effect of short distance transport under commercial conditions on the physiology of slaughter calves; $\mathrm{pH}$ and colour profiles of veal. Livest Prod Sci. (2003) 82:171-9. doi: 10.1016/S0301-6226(03) 00010-1

10. Pardon B, Catry B, Dewulf J, Persoons D, Hostens M, De Bleecker $\mathrm{K}$, et al. Prospective study on quantitative and qualitative antimicrobial and anti-inflammatory drug use in white veal calves. J Antimicrob Chemother. (2012) 67:1027-38. doi: 10.1093/jac/ dkr570

11. Pardon B, Hostens M, Duchateau L, Dewulf J, De Bleecker K, Deprez P. Impact of respiratory disease, diarrhea, otitis and arthritis on mortality and carcass traits in white veal calves. BMC Vet Res. (2013) 9:79. doi: 10.1186/1746-6148-9-79

12. Nonnecke BJ, Foote MR, Miller BL, Fowler M, Johnson TE, Horst RL. Effects of chronic environmental cold on growth, health, and select metabolic and immunologic responses of preruminant calves. J Dairy Sci. (2009) 92:613443. doi: $10.3168 /$ jds.2009-2517

13. Woolums A, Loneragan G, Hawkins L, Williams S. Baseline management practices and animal health data reported by US feedlots responding to a survey regarding acute interstitial pneumonia. Bovine Practitioner (2005) 39:116.

14. Nikunen S, Hartel H, Orro T, Neuvonen E, Tanskanen R, Kivela SL, et al. Association of bovine respiratory disease with clinical status and acute phase proteins in calves. Comp Immunol Microbiol Infect Dis. (2007) 30:143-51. doi: 10.1016/j.cimid.2006.11.004 
15. Snowder GD, Van Vleck LD, Cundiff LV, Bennett GL. Bovine respiratory disease in feedlot cattle: environmental, genetic, and economic factors. $J$ Anim Sci. (2006) 84:1999-2008. doi: 10.2527/jas.2006-046

16. Arcangioli MA, Duet A, Meyer G, Dernburg A, Bezille P, Poumarat F, et al. The role of Mycoplasma bovis in bovine respiratory disease outbreaks in veal calf feedlots. Vet J. (2008) 177:89-93. doi: 10.1016/j.tvjl.2007.03.008

17. Radaelli E, Luini M, Loria GR, Nicholas RAJ, Scanziani E. Bacteriological, serological, pathological and immunohistochemical studies of Mycoplasma bovis respiratory infection in veal calves and adult cattle at slaughter. Res Vet Sci. (2008) 85:282-90. doi: 10.1016/j.rvsc.2007.11.012

18. Stoltenow C, Vincent LL. Calf Scours: Causes, Prevention, Treatment. NDSU Extension Service (2003). Available online at: https://library.ndsu. edu/ir/bitstream/handle/10365/5323/as776.pdf?sequence $=1$ (Accessed Nov 21, 2017).

19. Liang, Y (2015). The Influences of Planes of Nutrition on Development and Health of the Gastrointestinal Tract of Calves. Lubbock, TX: Texas Tech University.

20. Verstegen MW, Williams BA. Alternatives to the use of antibiotics as growth promoters for monogastric animals. Anim Biotechnol. (2002) 13:113-27. doi: 10.1081/ABIO-120005774

21. European Commission. Regulation (EC) No 1831/2003 of the European Parliament and of the Council of 22 September 2003 on Additives for Use in Animal Nutrition. Brussels: European Commission (2017).

22. Mevius D, Koene M, Wit B, Pelt W, van Bondt N. MARAN 2009: Monitoring of Antimicrobial Resistance and Antibiotic Usage in Animals in the Netherlands in 2009. Wageningen: Wageningen University and Research Centre, Central Veterinary Institute (2009).

23. Pardon B, De Bleecker K, Hostens M, Callens J, Dewulf J, Deprez P. Longitudinal study on morbidity and mortality in white veal calves in Belgium. BMC Vet Res. (2012) 8:26. doi: 10.1186/1746-6148-8-26

24. Mevius D, Wit B, Van Pelt W, Puister-Jansen L, Bondt N, Bergevoet R, et al. MARAN 2007: Monitoring of Antimicrobial Resistance and Antibiotic Usage in Animals in the Netherlands in 2006/2007. Wageningen: Wageningen University and Research Centre, Central Veterinary Institute (2009).

25. Di Labio E, Regula G, Steiner A, Miserez R, Thomann A, Ledergerber $U$. Antimicrobial resistance in bacteria from Swiss veal calves at slaughter. Zoonoses Public hlth. (2007) 54:344-52. doi: 10.1111/j.1863-2378.2007.01071.x

26. Pletcher MJ, Pignone M. Evaluating the clinical utility of a biomarker: a review of methods for estimating health impact. Circulation (2011) 123:1116-24. doi: 10.1161/CIRCULATIONAHA.110.943860

27. Wilson BK, Richards CJ, Step DL, Krehbiel CR. Best management practices for newly weaned calves for improved health and well-being. J Anim Sci. (2017) 95:2170-82. doi: 10.2527/jas2016.1006

28. Renaud DL, Duffield TF, LeBlanc SJ, Haley DB, Kelton DF. Clinical and metabolic indicators associated with early mortality at a milk-fed veal facility: a prospective case-control study. J Dairy Sci. (2018) 101:2669-78. doi: $10.3168 /$ jds.2017-14042

29. Knowles TG, Warriss PD, Brown SN, Edwards JE. Effects on cattle of transportation by road for up to 31 hours. Vet Rec. (1999) 145:575-82. doi: 10.1136/vr.145.20.575

30. Knowles T, Warriss P, Brown S, Edwards J, Watkins P, Phillips A. Effects on calves less than one month old of feeding or not feeding them during road transport of up to 24 hours. Vet Rec. (1997) 140:116-24. doi: 10.1136/vr.140.5.116

31. Grigor PN, Cockram MS, Steele WB, Le Sueur CJ, Forsyth RE, Guthrie JA, et al. Effects of space allowance during transport and duration of midjourney lairage period on the physiological, behavioural and immunological responses of young calves during and after transport. Anim Sci. (2001) 73:341-60. doi: 10.1017/S135772980005832X

32. Jongman EC, Butler KL. The effect of age, stocking density and flooring during transport on welfare of young dairy calves in australia. Animals (2014) 4:184-99. doi: 10.3390/ani4020184

33. Mormede P, Soissons J, Bluthe RM, Raoult J, Legarff G, Levieux D, et al. Effect of transportation on blood serum composition, disease incidence, and production traits in young calves. Influence of the journey duration. Ann Rech Vet. (1982) 13:369-84.
34. Knowles TG, Brown SN, Edwards JE, Phillips AJ, Warriss PD. Effect on young calves of a one-hour feeding stop during a 19-hour road journey. Vet Rec. (1999) 144:687-92. doi: 10.1136/vr.144.25.687

35. Fazio E, Ferlazzo A. Evaluation of stress during transport. Vet Res Commun. (2003) 27(Suppl. 1):519-24. doi: 10.1023/B:VERC.0000014211.87613.d9

36. Minka NS, Ayo JO. Physiological responses of food animals to road transportation stress. Afr J Biotechnol. (2010) 9:6601-13.

37. Sporer KRB, Burton JL, Earley B, Crowe MA. Transportation stress in young bulls alters expression of neutrophil genes important for the regulation of apoptosis, tissue remodeling, margination, and anti-bacterial function. Vet Immunol Immunop. (2007) 118:19-29. doi: 10.1016/j.vetimm.2007. 04.002

38. Hulbert LE, Cobb CJ, Carroll JA, Ballou MA. The effects of early weaning on innate immune responses of Holstein calves. J Dairy Sci. (2011) 94:2545-56. doi: $10.3168 /$ jds.2010-3983

39. Hulbert LE, Cobb CJ, Carroll JA, Ballou MA. Effects of changing milk replacer feedings from twice to once daily on Holstein calf innate immune responses before and after weaning. J Dairy Sci. (2011) 94:2557-65. doi: 10.3168/jds.2010-3980

40. Broom DM. Causes of poor welfare in large animals during transport. Vet Res Commun. (2003) 27(Suppl. 1):515-8. doi: 10.1023/B:VERC.0000014210.29852.9a

41. Dhabhar FS, Mcewen BS. Acute stress enhances while chronic stress suppresses cell-mediated immunity in vivo: a potential role for leukocyte trafficking. Brain Behav Immun. (1997) 11:286-306. doi: 10.1006/brbi.1997.0508

42. Moberg GP. Biological response to stress: implications for animal welfare. In: Moberg GP and Mench JA, editor. The Biology of Animal Stress: Basic Principles and Implications for Animal Welfare. Wallingford: CAB International (2000). p. 1-21.

43. Vegas O, Garmendia L, Arregi A, Azpiroz A. Effects of social stress on immunomodulation and tumor development. In: Armstrong AW, editor. Advances in Malignant Melanoma-Clinical and Research Perspectives. In Tech (2011). p. 225-52.

44. Mormede P, Andanson S, Auperin B, Beerda B, Guemene D, Malmkvist $\mathrm{J}$, et al. Exploration of the hypothalamic-pituitary-adrenal function as a tool to evaluate animal welfare. Physiol Behav. (2007) 92:317-39. doi: 10.1016/j.physbeh.2006.12.003

45. Alberghina D, Medica P, Fazio E, Cavaleri S, Ferlazzo A. Effect of long distance road transport on serum cortisol and haematocrit in Limousine calves and influence of body weight decrease. Biotechnol Agron Soc Environ. (2001) 5:73.

46. Odore R, D'Angelo A, Badino P, Bellino C, Pagliasso S, Re G. Road transportation affects blood hormone levels and lymphocyte glucocorticoid and beta-adrenergic receptor concentrations in calves. Vet J. (2004) 168:297303. doi: 10.1016/j.tvjl.2003.09.008

47. Fujiwara $\mathrm{T}$, Cherrington $\mathrm{AD}$, Neal DN, McGuinness OP. Role of cortisol in the metabolic response to stress hormone infusion in the conscious dog. Metabolis. (1996) 45:571-8. doi: 10.1016/S0026-0495(96) 90026-8

48. Bernardini D, Gerardi G, Peli A, Nanni Costa L, Amadori M, Segato S. The effects of different environmental conditions on thermoregulation and clinical and hematological variables in long-distance roadtransported calves. J Anim Sci. (2012) 90:1183-91. doi: 10.2527/jas.20 11-4113

49. Aich P, Babiuk LA, Potter AA, Griebel P. Biomarkers for prediction of bovine respiratory disease outcome. OMICS (2009) 13:199-209. doi: 10.1089/omi.2009.0012

50. Rosmond R. Role of stress in the pathogenesis of the metabolic syndrome. Psychoneuroendocrino. (2005) 30:1-10. doi: 10.1016/j.psyneuen.2004.05.007

51. DeRijk RH, Petrides J, Deuster P, Gold PW, Sternberg EM. Changes in corticosteroid sensitivity of peripheral blood lymphocytes after strenuous exercise in humans. J Clin Endocrinol Metab. (1996) 81:228-35.

52. DeRijk R, Sternberg EM. Corticosteroid resistance and disease. Ann Med. (1997) 29:79-82. doi: 10.3109/07853899708998746

53. Deuster PA, Zelazowska EB, Singh A, Sternberg EM. Expression of lymphocyte subsets after exercise and dexamethasone in high and 
low stress responders. Med Sci Sports Exerc. (1999) 31:1799-806. doi: 10.1097/00005768-199912000-00016

54. Negrao JA, Porcionato MA, De Passille AM, Rushen J. Cortisol in saliva and plasma of cattle after ACTH administration and milking. J Dairy Sci. (2004) 87:1713-8. doi: 10.3168/jds.S0022-0302(04)73324-X

55. Cook NJ. Minimally invasive sampling media and the measurement of corticosteroids as biomarkers of stress in animals. Can J Anim Sci. (2012) 92:227-59. doi: 10.4141/cjas2012-045

56. Warriss PD. The handling of cattle pre-slaughter and its effects on carcass and meat quality. Appl Anim Behav Sci. (1990) 28:171-86. doi: 10.1016/0168-1591(90)90052-F

57. Tarrant PV, Kenny FJ, Harrington D, Murphy M. Long-distance transportation of steers to slaughter-effect of stocking density on physiology, behavior and carcass quality. Livest Prod Sci. (1992) 30:223-38. doi: 10.1016/S0301-6226(06)80012-6

58. Von Borell E. The biology of stress and its application to livestock housing and transportation assessment. J Anim Sci. (2001) 79(E-Suppl.):E260-E7. doi: 10.2527/jas2001.79E-SupplE260x

59. Naylor JM. A retrospective study of the relationship between clinical signs and severity of acidosis in diarrheic calves. Can Vet J. (1989) 30:577-80.

60. Renaud DL, Duffield TF, LeBlanc SJ, Ferguson S, Haley DB, Kelton DF. Risk factors associated with mortality at a milk-fed veal calf facility: a prospective cohort study. J Dairy Sci. (2018) 101:1-10. doi: 10.3168/jds.2017-13581

61. Winder CB, Kelton DF, Duffield TF. Mortality risk factors for calves entering a multi-location white veal farm in Ontario, Canada. J Dairy Sci. (2016) 99:10174-81. doi: 10.3168/jds.2016-11345

62. Cernicchiaro N, White BJ, Renter DG, Babcock AH, Kelly L, Slattery R. Associations between the distance traveled from sale barns to commercial feedlots in the United States and overall performance, risk of respiratory disease, and cumulative mortality in feeder cattle during 1997 to 2009. J Anim Sci. (2012) 90:1929-39. doi: 10.2527/jas.2011-4599

63. Babcock AH, Renter DG, White BJ, Dubnicka SR, Scott HM. Temporal distributions of respiratory disease events within cohorts of feedlot cattle and associations with cattle health and performance indices. Prev Vet Med. (2010) 97:198-219. doi: 10.1016/j.prevetmed.2010.09.003

64. Lechtenberg KF, Smith RA, Stokka GL. Feedlot health and management. Vet Clin North Am Food Anim Pract. (1998) 14:177-97. doi: 10.1016/S0749-0720(15)30250-4

65. Tadich N, Gallo C, Bustamante H, Schwerter M, van Schaik G. Effects of transport and lairage time on some blood constituents of Friesian-cross steers in Chile. Livest Prod Sci. (2005) 93:223-33. doi: 10.1016/j.livprodsci.2004.10.004

66. Broom D, Goode J, Hall S, Lloyd D, Parrott R. Hormonal and physiological effects of a15 hour road journey in sheep: comparison with the responses to loading, handling and penning in the absence of transport. Brit Vet J. (1996) 152:593-604. doi: 10.1016/S0007-1935(96)80011-X

67. Knowles TG, Warriss PD, Brown SN, Kestin SC, Rhind SM, Edwards JE, et al. Long distance transport of lambs and the time needed for subsequent recovery. Vet Rec. (1993) 133:286-93. doi: 10.1136/vr.133.12.286

68. Parrott RF, Thornton SN, Robinson JE. Endocrine responses to acute stress in castrated rams-no increase in oxytocin but evidence for an inverse relationship between cortisol and vasopressin. Acta Endocrinol (Copenh) (1988) 117:381-6. doi: 10.1530/acta.0.1170381

69. Pare J, Thurmond MC, Gardner IA, Picanso JP. Effect of birthweight, total protein, serum IgG and packed cell volume on risk of neonatal diarrhea in calves on two California dairies. Can J Vet Res. (1993) 57:241-6.

70. Turkson PK, Ganyo EY. Relationship between haemoglobin concentration and packed cell volume in cattle blood samples. Onderstepoort J Vet. (2015) 82:a863. doi: 10.4102/ojvr.v82i1.863

71. Cole NA, Camp TH, Rowe Jr LD, Stevens DG, Hutcheson DP. Effect of transport on feeder calves. Am J Vet Res. (1988) 49:178-83.

72. Seifi HA, Mohri M, Shoorei E, Farzaneh N. Using haematological and serum biochemical findings as prognostic indicators in calf diarrhoea. Comp Clin Pathol. (2006) 15:143-7. doi: 10.1007/s00580-0060620-8

73. Klee W, Schillinger D, Dirksen G. Blood urea concentration and hematocrit in calf diarrhea: diagnostic and prognostic value. Deut Tierarztl Woch. (1979) $86: 465$.
74. Swanson J, Morrow-Tesch J. Cattle transport: historical, research, and future perspectives. J Anim Sci. (2001) 79(E-Suppl.):E102-E9. doi: 10.2527/jas2001.79E-SupplE102x

75. Wilson L, Egan C, Drake T. Blood, Growth, and other characteristics of special-fed, veal calves in private cooperation herds1. J Dairy Sci. (1994) 77:2477-85. doi: 10.3168/jds.S0022-0302(94)77189-7

76. Wilson L, Smith J, Smith D, Swanson D, Drake T, Wolfgang D, et al. Characteristics of veal calves upon arrival, at 28 and 84 days, and at end of the production cycle1. J Dairy Sci. (2000) 83:843-54. doi: 10.3168/jds.S0022-0302(00)74948-4

77. Naylor JM, Kronfeld DS, Bech-Nielsen S, Bartholomew RC. Plasma total protein measurement for prediction of disease and mortality in calves. J Am Vet Med Assoc. (1977) 171:635-8.

78. Rea DE, Tyler JW, Hancock DD, Besser TE, Wilson L, Krytenberg DS, et al. Prediction of calf mortality by use of tests for passive transfer of colostral immunoglobulin. J Am Vet Med A. (1996) 208:2047-9.

79. Pardon B, Alliet J, Boone R, Roelandt S, Valgaeren B, Deprez P. Prediction of respiratory disease and diarrhea in veal calves based on immunoglobulin levels and the serostatus for respiratory pathogens measured at arrival. Prev Vet Med. (2015) 120:169-76. doi: 10.1016/j.prevetmed.2015.04.009

80. Tothova C, Nagy O, Kovac G. Acute phase proteins and their use in the diagnosis of diseases in ruminants: a review. Vet Med. (2014) 59:163-80. doi: 10.17221/7478-VETMED

81. Horadagoda NU, Knox KMG, Gibbs HA, Reid SWJ, Horadagoda A, Edwards SER, et al. Acute phase proteins in cattle: discrimination between acute and chronic inflammation. Vet Rec. (1999) 144:437-41. doi: 10.1136/vr.144.16.437

82. Humblet MF, Coghe J, Lekeux P, Godeau JM. Acute phase proteins assessment for an early selection of treatments in growing calves suffering from bronchopneumonia under field conditions. Res Vet Sci. (2004) 77:41-7. doi: 10.1016/j.rvsc.2004.02.009

83. Schneider A, Correa MN, Butler WR. Short communication: acute phase proteins in Holstein cows diagnosed with uterine infection. Res Vet Sci. (2013) 95:269-71. doi: 10.1016/j.rvsc.2013.02.010

84. Jacobsen S, Andersen PH, Toelboell T, Heegaard PM. Dose dependency and individual variability of the lipopolysaccharide-induced bovine acute phase protein response. J Dairy Sci. (2004) 87:3330-9. doi: $10.3168 /$ jds.S0022-0302(04)73469-4

85. Petersen HH, Nielsen JP, Heegaard PM. Application of acute phase protein measurements in veterinary clinical chemistry. Vet Res. (2004) 35:163-87. doi: 10.1051/vetres:2004002

86. Stocker R, Yamamoto Y, Mcdonagh AF, Glazer AN, Ames BN. Bilirubin is an antioxidant of possible physiological importance. Science (1987) 235:1043-6. doi: 10.1126/science.3029864

87. Bertoni G, Trevisi E, Han X, Bionaz M. Effects of inflammatory conditions on liver activity in puerperium period and consequences for performance in dairy cows. J Dairy Sci. (2008) 91:3300-10. doi: 10.3168/jds.2008-0995

88. Spears JW. Reevaluation of the metabolic essentiality of the minerals-Review. Asian Australasian J Anim. (1999) 12:1002-8. doi: 10.5713/ajas.1999.1002

89. Schaefer AL, Jones SDM, Tong AKW, Young BA. Effects of transport and electrolyte supplementation on ion concentrations, carcass yield and quality in bulls. Can J Anim Sci. (1990) 70:107-19. doi: 10.4141/cjas90-012

90. Schaefer AL, Jones SDM, Stanley RW. The use of electrolyte solutions for the reducing transport stress. J Anim Sci. (1997) 75:258-65. doi: $10.2527 / 1997.751258 \mathrm{x}$

91. Parker AJ, Hamlin GP, Coleman CJ, Fitzpatrick LA. Quantitative analysis of acid-base balance in Bos indicus steers subjected to transportation of long duration. J Anim Sci. (2003) 81:1434-9. doi: 10.2527/2003.8161434x

92. Davidson A, McConnico R, Mitchell M, Hubert J, Coates-Markle L. The effect of pre-treatment with oral electrolytes on serum cortisol and other haematological parameters in a group of feral horses transported by road. Vet J. (2004) 168:199.

93. Grigor PN, Cockram MS, Steele WB, McIntyre J, Williams CL, Leushuis IE, et al. A comparison of the welfare and meat quality of veal calves slaughtered on the farm with those subjected to transportation and lairage. Livest Prod Sci. (2004) 91:219-28. doi: 10.1016/j.livprodsci.2004.08.005

94. Klinkon M, JeŽek J. Values of blood variables in calves. In: Perez-Marin CC, editor. A Bird's-Eye View of Veterinary Medicine. InTech (2012). p. 301-20. 
95. Maach L, Gründer H, Boujija A. Klinische und hämatologische Untersuchungen bei schwarzbunten an Durchfall erkrankten neugeborenen Aufzuchtkälbern in Marokko. Deut Tierarztl Woch. (1992) 99:133-40.

96. Constable P. The treatment of the diarrheic calf: an update. In: Recent Developments and Perspectives in Bovine Medicine: Keynote Lectures of the 22nd World Buiatrics Congress. Hannover (2002).

97. Trefz FM, Lorch A, Feist M, Sauter-Louis C, Lorenz I. The prevalence and clinical relevance of hyperkalaemia in calves with neonatal diarrhoea. Vet $J$. (2013) 195:350-6. doi: 10.1016/j.tvjl.2012.07.002

98. Brownlow MA, Hutchins DR. The concept of osmolality-its use in the evaluation of dehydration in the horse. Equine Vet J. (1982) 14:106-10. doi: 10.1111/j.2042-3306.1982.tb02358.x

99. Kaneko J, Harvey JW, Bruss, M.L. Clinical Biochemistry of Domestic Animals. San Diego, CA: Academic Press (2008).

100. Griffin D, Chengappa MM, Kuszak J, McVey DS. Bacterial pathogens of the bovine respiratory disease complex. Vet Clin North Am Food Anim Pract. (2010) 26:381-94. doi: 10.1016/j.cvfa.2010.04.004

101. Rifkind JM, Zhang L, Heim JM, Levy A. The role of hemoglobin in generating oxyradicals. In: Simic MG, Taylor KA, Ward JF, von Sonntag C, editors. Oxygen Radicals in Biology and Medicine. New York, NY: Plenum Press (1988). p. 157-62.

102. Reece W, Hotchkiss D. Blood studies and performance among calves reared by different methods1. J Dairy Sci. (1987) 70:1601-11. doi: 10.3168/jds.S0022-0302(87)80188-1

103. Gygax M, Hirni H, Zwahlen R, Lazary S, Blum JW. Immune functions of veal calves fed low amounts of iron. Zentralbl Veterinarmed A. (1993) 40:345-58. doi: 10.1111/j.1439-0442.1993.tb00638.x

104. Miltenburg GAJ, Wensing T, Vanvliet JPM, Schuijt G, Vandebroek J, Breukink HJ. Blood hemoglobin, plasma iron, and tissue iron in dams in late gestation, at calving, and in veal calves at delivery and later. J Dairy Sci. (1991) 74:3086-94. doi: 10.3168/jds.S0022-0302(91)78494-4

105. European Food Safety Authority. Welfare of beef cattle and calves. EFSA J. (2012) 10:2669. doi: 10.2903/j.efsa.2012.2669

106. Bami MH, Mohri M, Seifi HA, Tabatabaee AAA. Effects of parenteral supply of iron and copper on hematology, weight gain, and health in neonatal dairy calves. Vet Res Commun. (2008) 32:553-61. doi: 10.1007/s11259-008-9058-6

107. Oppenheimer SJ. Iron and its relation to immunity and infectious disease. $J$ Nutr. (2001) 131(2S-2):616S-35S. doi: 10.1093/jn/131.2.616S

108. Steinhardt M, Thielscher HH. The effect of haemoglobin content of blood on the reactions of suckler calves exposed to short haul road transport and temporary separation from herd mates. Tieraerztl Umschau. (2005) 60:356.

109. Blum JW, Hammon H. Endocrine and metabolic aspects in milk-fed calves. Domest Anim Endocrinol. (1999) 17:219-30. doi: 10.1016/S0739-7240(99)00039-9

110. Enjalbert F. The relationship between trace elements status and health in calves. Rev Med Vet. (2009) 160:429-35. Available online at: https://www. agweb.com/assets/1/6/D11021.pdf

111. Todd SE, Mellor DJ, Stafford KJ, Gregory NG, Bruce RA, Ward RN. Effects of food withdrawal and transport on 5- to 10-day-old calves. Res Vet Sci. (2000) 68:125-34. doi: 10.1053/rvsc. 1999.0345

112. Chacon G, Garcia-Belenguer S, Villarroel M, Maria GA. Effect of transport stress on physiological responses of male bovines. Deut Tierarztl Woch. (2005) 112:465-9. Available online at: http://europepmc.org/abstract/med/ 16425633

113. Johnston K, Holcombe SJ, Hauptman JG. Plasma lactate as a predictor of colonic viability and survival after 360 degrees volvulus of the ascending colon in horses. Vet Sur. (2007) 36:563-7. doi: 10.1111/j.1532-950X.2007.00305.x

114. Zacher LA, Berg J, Shaw SP, Kudej RK. Association between outcome and changes in plasma lactate concentration during presurgical treatment in dogs with gastric dilatation-volvulus: 64 cases (20022008). J Am Vet Med A. (2010) 236:892-7. doi: 10.2460/javma.236. 8.892

115. Boulay G, Francoz D, Dore E, Dufour S, Veillette M, Badillo M, et al. Preoperative cow-side lactatemia measurement predicts negative outcome in Holstein dairy cattle with right abomasal disorders. J Dairy Sci. (2014) 97:212-21. doi: 10.3168/jds.2013-6898
116. Lorenz I. Influence of D-lactate on metabolic acidosis and on prognosis in neonatal calves with diarrhoea. J Vet Med A Physiol Pathol Clin Med. (2004) 51:425-8. doi: 10.1111/j.1439-0442.2004.00662.x

117. Lorenz I. D-Lactic acidosis in calves. Vet J. (2009) 179:197-203. doi: 10.1016/j.tvjl.2007.08.028

118. Lorenz I, Vogt S. Investigations on the association of D-lactate blood concentrations with the outcome of therapy of acidosis, and with posture and demeanour in young calves with diarrhoea. J Vet Med A Physiol Pathol Clin Med. (2006) 53:490-4. doi: 10.1111/j.1439-0442.2006. 00863.x

119. Naylor JM. Severity and nature of acidosis in diarrheic calves over and under one week of age. Can Vet J. (1987) 28:168-73.

120. Coghe J, Uystepruyst CH, Bureau F, Detilleux J, Art T, Lekeux P. Validation and prognostic value of plasma lactate measurement in bovine respiratory disease. Vet J. (2000) 160:139-46. doi: 10.1016/S1090-0233(00) 90487-8

121. Buczinski S, Rademacher RD, Tripp HM, Edmonds M, Johnson EG, Dufour S. Assessment of L-lactatemia as a predictor of respiratory disease recognition and severity in feedlot steers. Prev Vet Med. (2015) 118:306-18. doi: 10.1016/j.prevetmed.2014.12.003

122. Tyler $H$, Ramsey $H$. Hypoxia in neonatal calves: effect on selected metabolic parameters. J Dairy Sci. (1991) 74:1957-62. doi: 10.3168/jds.S0022-0302(91)78362-8

123. Morris DD, Cullor JS, Whitlock RH, Wickstrom M, Corbeil LB. Endotoxemia in neonatal calves given antiserum to a mutant Escherichia coli (J-5). Am J Vet Res. (1986) 47:2554-65.

124. Guterbock WM. The impact of BRD: the current dairy experience. Anim Health Res Rev. (2014) 15:130-4. doi: 10.1017/S1466252314000140

125. Frohli D, Blum JW. Effects of fasting on blood plasma levels, metabolism and metabolic effects of epinephrine and norepinephrine in steers. Acta Endocrinol (Copenh). (1988) 118:254-9. doi: 10.1530/acta.0.1180254

126. Cole NA, Phillips WA, Hutcheson DP. The effect of pre-fast diet and transport on nitrogen metabolism of calves. J Anim Sci. (1986) 62:1719-31. doi: $10.2527 /$ jas $1986.6261719 \mathrm{x}$

127. Ishiwata T, Uetake K, Eguchi Y, Tanaka T. Steer stress levels during long distance transport throughout the year in Japan. Anim Sci J. (2008) 79:510-7. doi: 10.1111/j.1740-0929.2008.00557.x

128. Radostits O, Gay CC, Hinchcliff K, Constable P, Jacobs D, Ikede B, et al. Veterinary Medicine: A Textbook of the Diseases of Cattle, Sheep, Pigs, Goats and Horses. Edinburgh, UK: Saunders Elsevier (2007). p. 795-8.

129. van Eerdenburg FJ, Adewuyi S, editors. A relationship between the activity and NEFA-level of postpartum dairy cows. In: Animals and Environment, Vol. 1, Proceedings of the XIIth ISAH Congress on Animal Hygiene. Warsaw (2005).

130. Collard BL, Boettcher PJ, Dekkers JCM, Petitclerc D, Schaeffer LR. Relationships between energy balance and health traits of dairy cattle in early lactation. J Dairy Sci. (2000) 83:2683-90. doi: 10.3168/jds.S0022-0302(00)75162-9

131. Fenwick MA, Llewellyn S, Fitzpatrick R, Kenny DA, Murphy JJ, Patton $\mathrm{J}$, et al. Negative energy balance in dairy cows is associated with specific changes in IGF-binding protein expression in the oviduct. Reproduction (2008) 135:63-75. doi: 10.1530/REP-07-0243

132. Seppa-Lassila L, Eerola U, Orro T, Hartel H, Simojoki H, Autio T, et al. Health and growth of Finnish beef calves and the relation to acute phase response. Livest Sci. (2017) 196:7-13. doi: 10.1016/j.livsci.2016. 12.007

133. Fayet J, Overwater J. Prognosis of diarrhoea in the newborn calf: statistical analysis of blood biochemical data. Ann Rech Vet. (1978) 9:55-61.

134. Kent JE, Ewbank R. The effect of road transportation on the blood constituents and behaviour of calves. I. Six months old. Br Vet J. (1983) 139:228-35

135. Kent JE, Ewbank R. The effect of road transportation on the blood constituents and behaviour of calves. III. Three months old. Br Vet J. (1986) 142:326-35.

136. Kent JE, Ewbank R. The effect of road transportation on the blood constituents and behaviour of calves. II. One to three weeks old. $\mathrm{Br} \mathrm{Vet} J$. (1986) 142:131-40. 
137. Trunkfield HR, Broom DM. The Welfare of Calves during Handling and Transport. Appl Anim Behav Sci. (1990) 28:135-52.

138. Steiger M, Senn M, Altreuther G, Werling D, Sutter F, Kreuzer M, et al. Effect of a prolonged low-dose lipopolysaccharide infusion on feed intake and metabolism in heifers. J Anim Sci. (1999) 77:2523-32.

139. Kushibiki S, Hodate K, Ueda Y, Shingu H, Mori Y, Itoh $\mathrm{T}$, et al. Administration of recombinant bovine tumor necrosis factor-alpha affects intermediary metabolism and insulin and growth hormone secretion in dairy heifers. J Anim Sci. (2000) 78:2164-71. doi: 10.2527/2000.7882164x

140. Montgomery SP, Sindt JJ, Greenquist MA, Miller WF, Pike JN, Loe $\mathrm{ER}$, et al. Plasma metabolites of receiving heifers and the relationship between apparent bovine respiratory disease, body weight gain, and carcass characteristics. J Anim Sci. (2009) 87:328-33. doi: 10.2527/jas. 2008-0969

141. Trefz FM, Feist M, Lorenz I. Hypoglycaemia in hospitalised neonatal calves: prevalence, associated conditions and impact on prognosis. Vet J. (2016) 217:103-8. doi: 10.1016/j.tvjl.2016.10.001

142. Cusack PM, McMeniman N, Lean IJ. The medicine and epidemiology of bovine respiratory disease in feedlots. Aust Vet J. (2003) 81:480-7. doi: 10.1111/j.1751-0813.2003.tb13367.x

143. Borderas FT, de Passille AMB, Rushen J. Temperature preferences and feed level of the newborn dairy calf. Appl Anim Behav Sci. (2009) 120:56-61. doi: 10.1016/j.applanim.2009.04.010

144. Hemsworth PH, Barnett JL, Beveridge L, Matthews LR. The Welfare of extensively managed dairy cattle: a review. Appl Anim Behav Sci. (1995) 42:161-82. doi: 10.1016/0168-1591(94)00538-P

145. Knowles TG. A review of post transport mortality among younger calves. Vet Rec. (1995) 137:406-7. doi: 10.1136/vr.137.16.406

146. Elmer S, Reinhold P. Consequences of changing ambient temperatures in calves-Part 1: immediate reactions of the respiratory system, the circulation system, metabolism and thermal regulation. Deut Tierarztl Woch. (2002) 109:182-92.

147. Burdick NC, Carroll JA, Hulbert LE, Dailey JW, Willard ST, Vann $\mathrm{RC}$, et al. Relationships between temperament and transportation with rectal temperature and serum concentrations of cortisol and epinephrine in bulls. Livest Sci. (2010) 129:166-72. doi: 10.1016/j.livsci.2010. 01.020

148. Behrends S, Schmidt T, Keisler D, Dailey J, Buntyn J, Sykes D, et al. Evaluation of the stress response of heifers during transportation. In: Joint Abstracts of the American Dairy Science and Society of Animal Science. Montreal, QC (2009).

149. Garcia M, Shin JH, Schlaefli A, Greco LF, Maunsell FP, Thatcher WW, et al. Increasing intake of essential fatty acids from milk replacer benefits performance, immune responses, and health of preweaned Holstein calves. $J$ Dairy Sci. (2015) 98:458-77. doi: 10.3168/jds.2014-838

150. McGuirk S, Ruegg P. Calf Diseases and Prevention. Available online at: http:// www.extention.org/pages/15695/calf-diseases-and-prevention/print (2017).

151. Galyean ML, Gunter SA, Malcolm-Callis KJ. Effects of arrival medication with tilmicosin phosphate on health and performance of newly received beef cattle. J Anim Sci. (1995) 73:1219-26. doi: 10.2527/1995.73 51219x

152. Baptiste K, Campbell J, Schumann F. Investigation into factors associated with hyperkalemia in diarrhoeic neonatal bovine calves. In: Proceedings of the 9th Intern Symp on Vet Epidemiology and Economics. (2000).

153. Avitsur R, Padgett DA, Sheridan JF. Social interactions, stress, and immunity. Neurol Clin. (2006) 24:483-91. doi: 10.1016/j.ncl.2006.03.005

154. Yun $\mathrm{CH}$, Wynn $\mathrm{P}$, Ha JK. Stress, acute phase proteins and immune modulation in calves. Anim Prod Sci. (2014) 54:1561-8. doi: 10.1071/AN14441

155. Burton JL, Madsen SA, Chang LC, Weber PSD, Buckham KR, van Dorp R, et al. Gene expression signatures in neutrophils exposed to glucocorticoids: a new paradigm to help explain "neutrophil dysfunction" in parturient dairy cows. Vet Immunol Immunopathol. (2005) 105:197-219. doi: 10.1016/j.vetimm.2005.02.012

156. Gupta S, Earley B, Crowe MA. Effect of 12-hour road transportation on physiological, immunological and haematological parameters in bulls housed at different space allowances. Vet J. (2007) 173:605-16. doi: $10.1016 /$ j.tvjl.2006.03.002
157. Villarroel M, Maria G, Sanudo C, Garcia-Belenguer S, Chacon G, GebreSenbet G. Effect of commercial transport in Spain on cattle welfare and meat quality. Deut Tierarztl Woch. (2003) 110:105-7. Available online at: http:// europepmc.org/abstract/med/12731109

158. Odore R, Badino P, Re G, Barbero R, Cuniberti B, D’Angelo A, et al. Effects of housing and short-term transportation on hormone and lymphocyte receptor concentrations in beef cattle. Res Vet Sci. (2011) 90:341-5. doi: 10.1016/j.rvsc.2010.05.026

159. Conner JG, Eckersall PD, Wiseman A, Aitchison TC, Douglas TA. Bovine acute phase response following turpentine injection. Res Vet Sci. (1988) 44:82-8.

160. Murray CF, Windeyer MC, Duffield TF, Haley DB, Pearl DL, Waalderbos $\mathrm{KM}$, et al. Associations of serum haptoglobin in newborn dairy calves with health, growth, and mortality up to 4 months of age. J Dairy Sci. (2014) 97:7844-55. doi: 10.3168/jds.2014-8465

161. Gånheim C, Hulten C, Carlsson U, Kindahl H, Niskanen R, Waller KP. The acute phase response in calves experimentally infected with bovine viral diarrhoea virus and/or Mannheimia haemolytica. Zoonoses Public Hlth. (2003) 50:183-90. doi: 10.1046/j.1439-0450.2003. 00658.x

162. Godson DL, Campos M, AttahPoku SK, Redmond MJ, Cordeiro DM, Sethi MS, et al. Serum haptoglobin as an indicator of the acute phase response in bovine respiratory disease. Vet Immunol Immunopathol. (1996) 51:277-92.

163. Angen $\varnothing$, Thomsen J, Larsen LE, Larsen J, Kokotovic B, Heegaard PM, et al. Respiratory disease in calves: microbiological investigations on transtracheally aspirated bronchoalveolar fluid and acute phase protein response. Vet Microbiol. (2009) 137:165-71. doi: 10.1016/j.vetmic.2008.12.024

164. Hajimohammadi A, Nazifi S, Ansari-Lari M, Khoshmanzar MR, Bigdeli SM. Identifying relationships among acute phase proteins (haptoglobin, serum amyloid A, fibrinogen, ceruloplasmin) and clinical findings in dairy calf diarrhea. Compar Clin Pathol. (2013) 22:227-32. doi: 10.1007/s00580-011-1390-5

165. Tothova C, Nagy O, Seide H, Kovac G. The effect of chronic respiratory diseases on acute phase proteins and selected blood parameters of protein metabolism in calves. Berl Munch Tierarztl. (2010) 123:307-13. doi: 10.2376/0005-9366-123-307

166. Skinner JG, Brown RA, Roberts L. Bovine haptoglobin response in clinically defined field conditions. Vet Rec. (1991) 128:147-9. doi: 10.1136/vr.128. 7.147

167. Hirvonen J, Eklund K, Teppo A, Huszenicza G, Kulcsar M, Saloniemi H, et al. Acue phase response in dairy cows with experimentally induced escherichia coli mastitis. Acta Vet Scand. (1999) 40:35-46.

168. Hulten C, Demmers S. Serum amyloid A (SAA) as an aid in the management of infectious disease in the foal: comparison with total leucocyte count, neutrophil count and fibrinogen. Equine Vet J. (2002) 34:693-8. doi: 10.2746/042516402776250360

169. Ganheim C, Alenius S, Waller KP. Acute phase proteins as indicators of calf herd health. Vet J. (2007) 173:645-51. doi: 10.1016/j.tvjl.2006.01.011

170. Carter JN, Meredith GL, Montelongo M, Gill DR, Krehbiel CR, Payton $\mathrm{ME}$, et al. Relationship of vitamin E supplementation and antimicrobial treatment with acute-phase protein responses in cattle affected by naturally acquired respiratory tract disease. Am J Vet Res. (2002) 63:1111-7. doi: 10.2460/ajvr.2002.63.1111

171. Heegaard PM, Godson DL, Toussaint MJ, Tjornehoj K, Larsen LE, Viuff B, et al. The acute phase response of haptoglobin and serum amyloid A (SAA) in cattle undergoing experimental infection with bovine respiratory syncytial virus. Vet Immunol Immunopathol. (2000) 77:151-9. doi: 10.1016/S0165-2427(00)00226-9

172. Alsemgeest SP, Lambooy IE, Wierenga HK, Dieleman SJ, Meerkerk B, van Ederen AM, et al. Influence of physical stress on the plasma concentration of serum amyloid-A (SAA) and haptoglobin (Hp) in calves. Vet Q. (1995) 17:9-12.

173. Teixeira AM, Borges GF. Creatine kinase: structure and function. Bras J Biomotricity (2012) 6:53-65. Available online at: http://www.redalyc.org/ $\mathrm{html} / 930 / 93023658001 /$

174. Montane J, Marco I, Lopez-Olvera J, Manteca X, Lavin S. Transport stress in roe deer (Capreolus capreolus): effect of a short-acting antipsychotic. Anim Welfare (2002) 11:405-17. 
175. Lopez-Olvera JR, Marco I, Montane J, Lavin S. Transport stress in Southern chamois (Rupicapra pyrenaica) and its modulation by acepromazine. Vet J. (2006) 172:347-55. doi: 10.1016/j.tvjl.2005. 06.007

176. Averos X, Martin S, Riu M, Serratosa J, Gosalvez LF. Stress response of extensively reared young bulls being transported to growing-finishing farms under Spanish summer commercial conditions. Livest Sci. (2008) 119:17482. doi: 10.1016/j.livsci.2008.04.002

177. Warriss PD, Brown SN, Knowles TG, Kestin SC, Edwards JE, Dolan SK, et al. Effects on cattle of transport by road for up to 15 hours. Vet Rec. (1995) 136:319-23.

178. Guardia MD, Estany J, Balasch S, Oliver MA, Gispert M, Diestre A. Risk assessment of skin damage due to pre-slaughter conditions and RYR1 gene in pigs. Meat Sci. (2009) 81:745-51. doi: 10.1016/j.meatsci.2008.11.020

179. Boyd JW. The mechanisms relating to increases in plasma enzymes and isoenzymes in diseases of animals. Vet Clin Pathol. (1983) 12:9-24. doi: 10.1111/j.1939-165X.1983.tb00609.x

180. Cuestas RA, Jr. Creatine kinase isoenzymes in high-risk infants. Pediatr Res. (1980) 14:935-8.

181. Drent M, Cobben NAM, Henderson RF, Wouters EFM, vanDieijenVisser M. Usefulness of lactate dehydrogenase and its isoenzymes as indicators of lung damage or inflammation. Eur Respir J. (1996) 9:1736-42. doi: 10.1183/09031936.96.09081736

182. Schultze AE, Gunaga KP, Wagner JG, Hoorn CM, Moorehead WR, Roth RA. Lactate dehydrogenase activity and isozyme patterns in tissues and bronchoalveolar lavage fluid from rats treated with monocrotaline pyrrole. Toxicol Appl Pharm. (1994) 126:301-10. doi: 10.1006/taap.199 4.1120

183. Col R, Uslu U. Changes in selected serum components in cattle naturally infected with Theileria annulata. Bull Vet Inst Pulawy (2007) 51:15-8. Available online at: http://www.piwet.pulawy.pl/bulletin/images/stories/pdf/ 20071/20071015018.pdf

184. Uetake K, Ishiwata T, Tanaka T, Sato S. Physiological responses of young cross-bred calves immediately after long-haul road transportation and after one week of habituation. Anim Sci J. (2009) 80:705-8. doi: 10.1111/j.1740-0929.2009.00693.x
185. Ilyin SE, Belkowski SM, Plata-Salaman CR. Biomarker discovery and validation: technologies and integrative approaches. Trends Biotechnol. (2004) 22:411-6. doi: 10.1016/j.tibtech.2004.06.005

186. Seo D, Ginsburg GS. Genomic medicine: bringing biomarkers to clinical medicine. Curr Opin Chem Biol. (2005) 9:381-6. doi: 10.1016/j.cbpa.2005.06.009

187. Witkamp R. Genomics and systems biology-how relevant are the developments to veterinary pharmacology, toxicology and therapeutics? J Vet Pharmacol Ther. (2005) 28:235-45. doi: 10.1111/j.1365-2885.2005.00662.x

188. Moore RE, Kirwan J, Doherty MK, Whitfield PD. Biomarker discovery in animal health and disease: the application of post-genomic technologies. Biomark Insights (2007) 2:185-96. doi: 10.1177/117727190700200040

189. Feilotter HE. Microarrays in veterinary diagnostics. Anim Health Res Rev. (2004) 5:249-55. doi: 10.1079/AHR200478

190. Wilkins MR, Sanchez JC, Gooley AA, Appel RD, HumpherySmith I, Hochstrasser DF, et al. Progress with proteome projects: why all proteins expressed by a genome should be identified and how to do it. Biotechnol Genet Eng. (1996) 13:19-50.

191. Oresic M, Vidal-Puig A, Hanninen V. Metabolomic approaches to phenotype characterization and applications to complex diseases. Expert Rev Mol Diagn. (2006) 6:575-85. doi: 10.1586/14737159.6.4.575

192. Griffin JL. Understanding mouse models of disease through metabolomics. Curr Opin Chem Biol. (2006) 10:309-15. doi: 10.1016/j.cbpa.2006.06.027

Conflict of Interest Statement: The authors declare that the research was conducted in the absence of any commercial or financial relationships that could be construed as a potential conflict of interest.

Copyright (C) 2018 Marcato, van den Brand, Kemp and van Reenen. This is an open access article distributed under the terms of the Creative Commons Attribution License (CC BY). The use, distribution or reproduction in other forums is permitted, provided the original author(s) and the copyright owner are credited and that the original publication in this journal is cited, in accordance with accepted academic practice. No use, distribution or reproduction is permitted which does not comply with these terms. 